\title{
The impossibility of the pluralistic hypothesis of John Hick as a ground for the christian relationship with the non-christians. II'.
}

\author{
Cf. Estudio Agustinano 44 (2009) 439-503.
}

\section{THE IMPOSSIBILITY OF THE PLURALISTIC HYPOTHESIS AS A BASIS FOR INTER-RELIGIOUS DIALOQUE}

\section{Introduction}

Having giving a detailed elaboration of the position of Hick, it is now a moment to see if it can be a guiding principle for the Christians in their relations with the non-Christians and especially, to the great world religions especially Judaism, Hinduism, Islam and Buddhism. ${ }^{1}$ It is possible in this chapter to refer to some of the already mentioned Hickian ideas especially in the moment of clarification or elaboration of the difficult related to the thought.

No doubt, the position of Hick has provoked different reactions and even polemical ones academically due to fact that his position has somehow been very radical in comparison to other pluralists, something that is in Hick's awareness.

"I realize that, however that what I'm going to say can only appear as an undermining of faith, as a heresy or apostasy, to many at the more con-

\footnotetext{
${ }^{1}$ CF. J. Hick, The Rainbow of Faiths, 12.
} 
servative end of Christianity spectrum. It is also true that some of positions taken by a very conservative Christian on the issue strike others of us as no longer tenable."2

It is also true that there are many arguments against Hick but it is not easy to put all of them here or to evaluate all the deficiencies in the hypothesis proposed by him.

In order to facilitate the study on the different criticisms I propose to put them into two groups: those, which are more theologically based and those whose weight is in the area of philosophy. It is possible for someone else to prefer another approach, such as that of Gavin D'Costa. ${ }^{3}$ It is also necessary to say that the twofold division is not so sharply distinguished because there is a possibility of interrelationship between the themes touched. I am not going to deal directly with the responses given by John Hick to some of the criticisms directed to his thought as they can be easily found in some of his works. ${ }^{4}$

\section{PART I: PHILOSOPHICAL OBJECTIONS}

\subsubsection{Methodological inconsistency?}

Hick has been accused of inconsistency, tautology and self-contradiction in some of his premises, in the development of his argument for his pluralistic hypothesis. 5 Hick claims to develop his hypothesis free from any influence, that is, it does not depend to any particular tradition or any philosophical system although as it has been seen, is found relying for example on Wittgenstein and I. Kant thoughts. In the same way, he claims that his is an inductive work resulting from observation of the phenomena of religions in the world. He stressed this saying: "I would like, hower, to stress the phrase people of different faiths because I am going to suggest that the way forward in this perplexity area is to be found by looking first at the actual lives of the people within the contexts of our own and other traditions."6

2 ibid., 15 .

${ }^{3}$ CF. G. D'Costa, John Hick's Theology of Religions. Critical Evaluation, (London, 1987).

${ }^{4}$ CF. J. HICK, The Rainbow of Faiths, 31-124; J. HICK, An Interpretation, passim.

${ }^{5}$ CF. T. R. STINNETT, "John Hick Pluralist Theory of Religion", 569.

${ }^{6} \mathrm{~J}$. HICK, The Rainbow of Faiths, 12. 
Hick adopts in his presupposition the nature of religion in the line of Wittgenstein, conceiving of them as cultural linguistic systems, a kind of language game, which enables him to make possible corresponding forms of life, experience and expressions. ${ }^{7}$ The religions according to Hick are formed around a practical soteriological aim, which is centred on the transformation toward the ultimate real according to ones internal and cultural influences and the influence of the ultimate. Tension is found in the very base of his theory, according to $S$. R. Twiss, because in one side it adheres to Wittgensteinian view of religious language and belief, which is usually understood to conceive of divine reality as internally related to practises and to construe religious discourse as grammatical rather than referential, while in the other side when examined with great care, it will be found that his theory is bound to the view that religious language and the beliefs are taken and understood as presupposing an independent and ontological real ultimate divine as a point of -let us say- union of all the religions, which has nothing to do with believing subject. ${ }^{8}$ The great difficult is how to hold them coherently because they are two different orientations to the epistemology of religious belief: the grammatical and the realist. Against these, K. Ward advises Hick to recognize that religion is not just a question of theoretical belief because it implies many things in the life of the believers. When a religious tradition is contemplated, some of its central myths will resonate more than others and seem to illuminate human experience more and some of the experiences will have some coherence and compatibility with some subjective feelings enabling such a subject to live and further them faithfully throughout his life, in relation to the transcendent reality, which is felt within such experience. This does not mean that such experiences from different traditions would have equality as Hick as proposed. ${ }^{9}$

Hick initiates his theory by revising the meaning given to religion and the approach to the situation of religious diversity, acknowledging that the same soteriological process is found operating within the different religions, within their own traditions, which is nothing more than the transformation of the self towards the Real. He then adopts as a methodological assumption the basic religious conviction that religious experience and thought mediate real contact with a higher reality that in principle is veridical in relation to the religious experience.

\footnotetext{
${ }^{7}$ CF. J. HICK, An Interpretation of Religion, 3-4; 347-353.

8 S. B. TwIss, "The Philosophy of Religious Pluralism", 535.

${ }^{9} \mathrm{~K}$. WARD, Religion and Revelation, 323.
} 
Together with that assumption, Hick strongly asserts that within the great religious traditions there is equality with respect to the moral and spiritual fruits. This becomes fundamental in his hypothesis especially for the other arguments and the consequences, which follow from it. S. Twiss questions this methodological move examining it to see whether it does not violate the claims found and advanced by the religious traditions themselves especially with regard to soteriology, the transformation of the self, and the cultural influences on the different traditions. $H$. Netland finds it difficult to understand the claim that there is transition from the self-centeredness to reality centeredness because one is left in suspense for the exact meaning of that claim. If seriously taken, the soteriological concept in the different traditions includes something more than that movement. It seems that the soteriological differences acclaimed by the different religions have led Hick to adopt a kind of "lowest common denominator soteriology" 10 in order to clear a dirtied way by the conflicts born from the different conception of salvation. There is no justice with regard to the different religious traditions, which may believe in quite different things with different ends. 11

Varillon with a polemic tone says that, affirming that all religions have the same value is like affirming that they are equivalent ways, which sprouted from the same original truth and thus affirming that they are different derivation of this truth. He challenges such stand doubting that it might be a hidden ground for indifferentism respect to the truth, offering false conscience tranquillity, which is nothing than stopping the man's effort in search for the truth. Killing up his point, he says that in the confrontation with the other religions, one has to ask himself about the absolute, unique and irreplaceable elements, which Christianity has offered to one's life. Instead of diminishing and equalizing all the religions in pretension of rendering justice to them or imposing something that is not proper of such religions. Nobody should impose on the others, what he/she believes to be the truth because it violates their freedom. This is more serious if the one doing such a thing is a member of a religion, which has love as its centre. 12

This gives reason to $H$. Netland to criticise the hermeneutical adequacy of Hick's theory saying that it is inadequate as a general second order theory about religions because it fails to accept the same traditions

\footnotetext{
10 H. NetLAND, "Professor Hick and Religious Pluralism", 256.

11 ibid.,

12 F. VARILLON, El cristianismo ante las Grandes Religiones, 27-28.
} 
as they are with their truth claims, and their central views, hence reducing them to some views and concepts unacceptable to the defended traditions.

"A second order theory such as Hick's must develop an account that can accommodate traditions own orthodox understandings of doctrines, beliefs and concepts without reinterpreting or reducing these into other categories as we have seen for example considering some of them as a myth or a "lowest common denominator," which reduces all religious soteriologies to the terms of ordinary morality, that of transition from egoism to altruism. So Hick's approach fails to respect the first order religious traditions and their complexity something very important if one has to remain and have a point of reference in his relation to other (...)."13

Corliss questions the basic religious conviction adopted by Hick for it wrongly assumes that the primary cognitive content of religions is found in veridical religious experiences and that these are shaped by the traditional concepts and categories found in the same tradition. This reasoning makes him not to adopt such conviction in the very first place of his arguments. Corliss is convinced that the cognitive content of religions is found in their conception of life and in the claims made and not in the experiences to which they give rise, to think otherwise illegitimately analogizes the role of religious experience ${ }^{14}$ in a religion to the role of sense experiences in dealing with the world around us.

P. Eddy criticises Hick for misusing his source material because he did not take into consideration what was its original intention in the given tradition. Whay such criticism? Hick begins with the highly generalized Kantian insight that the human mind actively interprets sensory information in terms of its inherent mental concepts. More specifically, Hick focuses on the noumenal-phenomenal distinction that allowed Kant to distinguish between an entity as it is in itself and as it appears in the act of

${ }^{13}$ S. B. Twiss, "The Philosophy of Religious Pluralism", 543.

14 ibid., 521. Religious experience for Hick is a category intended by him to be equivalent to religious form of life. He seems to suggest that Wittgenstein was right to affirm the primacy of religious experience and practice over conventional religious organization and doctrine. So according to Hick the students of religion must investigate and understand religious experience within the context of religious forms of life rather than theological doctrines and formal religious regulations. For Wittgenstein religious experience is best understood as being aware of situations-in- the world in terms of background systems of religious concepts associated with particular traditions and being disposed both to see these situations as for example manifesting divine presence to act accordingly. Is to say that religious experience must be understood as being shaped conceptually by background social-linguistic-contextual religious conditioning and learning. All religious experience is properly understood as 'experiencing-as' in which the experience is conditioned by his or her background religious language games and forms of life. 
human perception. Now by taking this epistemological principle and applying in a very unkantian fashion to human religious experience, Hick seems to form a foundation for his response to the problem of conflicting conceptions, something difficult to be accepted in the system of thought be it morally or logically because the end does not justify the means. ${ }^{15}$

K. Surin sees Hick's method as a kind of narrative because of his tendency to present in an autobiographical model when prefacing his presentation of his discourse and especially of his Copernican revolution. The problem is that, these narratives are the second order narrative constituting an abstract second order discourse whose primary function is that of developing theological sense making. ${ }^{16}$ Surin baptized Hick's discourse on religious pluralism as a discourse on ethnography, anthropology and orientalism. He accuses Hick of being an opportunist and conformist in the sense that he tried to accommodate his method, his thought according to the needs in order to substantiate his arguments for a pluralistic theology of religions.17

The methodology adopted by Hick does not solve the existing problems. K. Surin gives the example of the common human history and a common relationship to the mysterious transcendent reality, which in the West is called God, as advocated by Hick. Against this, he questions if there can be a common human history as proposed by Hick. He refuted this saying that it would be like a dream to have such a common history as long as the existing political and economical order constitute a world system whose structures consign masses of human being into subjugation. He gives an example of a hungry nomad in Chad and the prosperous investment banker in Zurich who are claimed to have a common human history while maintaining the existing political and economic forces, which will maintain the nomad in his/her poverty and the well-off citizen of Zurich in his or her affluence. This is to maintain the reality in its existing unredeemed form. ${ }^{18}$ So instead of helping to solve the fundamental problem that led him to develop his thesis it brings worse results. ${ }^{19}$

${ }^{15}$ CF. P. EDDy, "Religious Pluralism and the Divine. Another look at John Hick's NeoKantian proposal", 469.

${ }^{16}$ CF. K. SuRIN, “Towards a 'Materialist Critique' of Religious Pluralism”, 656.

17 ibid., 664.

18 ibid., 665.

19 CF. G. D'CostA, "The Impossibility of a Pluralist View of Religions", 224-229. M. Thomas holds this in a different perspective challenging it as follows: "But do we want a return to the attitude that existed in Indian Christianity before the advent of the Portuguese? Hardly any Christian leader has advocated it." M. M. Tomas, "A Christ Centred Humanist Approach to other Religions in the Indian Pluralistic Context", 50. 
For Gavin D'Costa 20 the whole venture of the pluralist view of religions with the paradigms or typologies of pluralism, inclusivism and exclusivism as three approaches on the Christian relation on the other religious traditions are unsustainable because pluralism has failed to affirm the autonomous value of religious pluralism for it has no other way of doing that than resorting to exclusivism of its own kind. As it cannot tolerate the normative claims of each tradition, it is forced to call them myth. "The irony about pluralism is that is eventually intolerant towards most forms of orthodox religious belief, Christian or otherwise. Hence, whichever way Hick tries to answer the question, his answer reveals that he is an exclusivist and not a pluralist as he claims." 21 Hick is led by his own arguments into transcendental agnosticism. ${ }^{22}$ How can Hick appeal to the reality of a God of universal love if the Real, the noumenal realm exists independently of, and outside man's perception of it? Either reality is or is not personal or loving; or the implications of reality viewed theistically either are or are not true.23

\subsubsection{On the ontological postulate of a real}

The ontological postulate according to Hick-is required rationally in order to hold the pluralist hypothesis. The only reason, which makes this postulate sustainable, is internal one. This postulate -has already been seen in the second and third chapter but for the sake of reminding, I do repeat it here- makes an ontological claim affirming that there is an existence of a single divine noumenon that is the ultimate reference of the major religions. Secondly it makes an epistemological claim indicating that this noumenon cannot be directly experienced or known in itself, but at best, it can be known indirectly. This means that any knowledge about it can only be indirect and inferential. Moreover, with respect to the other types of religious conceptual schemes, this divine noumenon comes to

20 Gavin D'Costa (born 1958-) has made a deep study of the theology of religious pluralism as advocated by John Hick especially in his doctoral dissertation published in 1987 as: John Hick's Theology of Religions. A Critical Evaluation. (Lanham, University of America).

21 ibid., 229.

22 Transcendental agnosticism affirms the transcendent divine reality over against naturalistic positions while refusing to state that the eschaton may eventually be theistic rather than non -theistic. It tends to remain agnostic in order to overcome the objections that theistic God emerges at the end of the universe of faith rather than as originally at the centre. Cf. G. D'CostA, John Hick's Theology of Religions. A Critical Evaluation, 172.

23 CF. G. D'CostA, "The Impossibility of a Pluralist View of Religions", 183-85; 232. 
consciousness in terms of radically different concepts of personality and impersonality. 24

For some authors, this concept of the Real seems to bring back the idea of religion as was understood during the Enlightenment period in the philosophy of religion whereby religions were considered as product of human reasoning and thus without any reference to any transcendence reality outside man himself. Moreover, the idea of ultimate reality is culturally conditioned in the same way, as the idea of the religion is itself culturally conditioned as Hick had claimed. Dwelling on this one can say that Hick is advocating finally a kind of religion of reason without being conscious of it. Hick's position to base himself on categories, which are culturally free can prove to be unachievable and which can lead him to a kind of self-contradiction because one of his interest in developing his pluralistic hypothesis is to show that religions are not illusory nor man's product. ${ }^{25}$

\subsubsection{On the ontological claim}

The first problem which comes in mind is dilemma involved in this divine noumenon, which is essentially inaccessible and unknowable, to be relevant to the religious phenomenal without any change or modification within the religions themselves because in each religion or tradition exists already an epistemic status. P. Eddy sees this, for example, in the existence of a radically conflicting conception of divine reality in the different world religions in the form of personal and impersonal, although Hick has already tried to remove this obstacle by going far in postulating the divine noumenon, which is always experienced differently within the different traditions. ${ }^{26} \mathrm{~W}$. Rowe asks himself whether exists this reality designated by Hick's expression the "real" but he finds that even Hick himself seems not to know because he postulates it in order to provide a favourable account of the religious diversity in the world. This account, according to Hick, is the best explanation of the apparent equal ability of these diverse faiths to produce persons of great moral and religious sanctity. Therefore, Rowe concludes that,

"there is no Reality designated by Hick's expression the Real. I say this because Hick takes it to be a necessary feature of the Real in itself

\footnotetext{
24 CF. J. HICK, An Interpretation of Religion, 246-249.

25 CF. P. R. PANIzo, Op. cit., 46; also CF. J. M. VelasCo, "Dios en el universo religioso", 29.

26 CF. P. EdDY, Op. cit., 469-472.
} 
that it does not have the property of being personal or impersonal. . But if it is true that the Real in itself is not personal, it is exceedingly difficulty to deny as Hick does, that the Real is non-personal. Indeed, I take to be a necessary truth, if not a truth of logic, that whatever is real is either personal or non-personal. So by my lights there can be no such thing as Hick's Real in itself." 27

The problem which has been strongly advocated in relation to the postulate of this ontological status of the Hickian real can be summarised in the following way: Is it necessarily that the propositions made from premises be it logical or illogical, about a certain reality, produce an ontological status? Seen what Hick has postulated, seems to be that some metaphysical propositions made about the phenomena of religious pluralism, basing himself on the Kantian philosophy -although as he claims in his own style- necessarily produce an ontological reality which forms the ground of all religions.

This procedure has denied what is found in the history, in the phenomenology of religions and what the religions themselves believe or think themselves to rely on. I do not think that the world religions and their followers, for example the Christians do believe that the God in whom they believe is not God in himself but some kind of a conception or product of our culture and the impingement of the divine in itself. Here is where Hick is criticised of not respecting and taking the religions and even his own religion seriously. For E. O. Springsted, Hick seems as if to be guided by what has been called "the myth of the neutral observer." $\mathrm{He}$ fails to take seriously the relation between fact values of believers who want to engage seriously in dialogue with people of other religions. ${ }^{28} \mathrm{P}$. Almond suggests, with regard to the parable of the elephant that Hick pretends to be in a position to see clearly while the religions are not in such a possibility. ${ }^{29}$ Varillon has criticised this parable saying that it has reduced the religions to perspectives and subjective things without any relation with God. God is presented there like a static object without any communication while from Christian point of view there is a belief in God's self-communication. ${ }^{30}$ Peter Byrne challenges Hick's postulate of the Real saying that if man's knowledge is conditioned by various imper-

${ }^{27}$ W. RowE, "Religious Pluralism", 150.

${ }^{28}$ CF. E. O. SpringSTED, "Conditions of Dialogue: John Hick and Simone Weil”, 19-20; 25-30.

${ }^{29}$ CF. P. Almond, "John Hick Copernican Theology", 36-41.

${ }^{30}$ CF. F. VARILLON, Op. cit., 40. 
fections culturally conditioned, how could he know that there is single noumenal divine reality behind all our experiences? ${ }^{31}$

H. Netland criticises this postulate of divine noumenon in its elaboration especially the distinction made between the divine noumenon and the divine noumenon in itself and secondly the interpretation of their relationship. Is there any element of continuity between the two? This element, if there is, runs a risk because there is a great diversity among the conceptions or images of the divine and even the great differences are in the meanings given to such phenomena term as God, Nirvana etc. This gives an impression that there is no plausibility to maintain that they all denote the same reality. 32

The element of discontinuity, this highlights the strong Kantian influence. The main problem here is the lack of knowledge about the divine noumenon. If this noumenon cannot be known in itself, then is it all informative to refer to phenomenal religions conceptions as images or manifestations of it? Given the lack of knowledge about the real an sich; why should it be posited as a single divine reality than as a plurality of noumena? There is no other way of responding to this difficulty because it has been an attempt of Hick to escape the difficulties of the different truth claims between the theistic and non-theistic religions. 33 The very assertion that there is a lack of knowledge about it undermines its capacity to serve as a unifying factor hence giving the possibility of affirming anything about its ontological status. "If nothing at all can be said of the Real, then one cannot say that some expressions are more authentic manifestations of it than others. Indeed we cannot say that anything is a manifestation of it at all since that would make it a causal substratum,"34 says Keith Ward. If A manifests $\mathrm{B}$ then one must affirm also that $\mathrm{B}$ is caused by $\mathrm{A}$ but it is not allowed in the reasoning of Hick. So why should we not emit the concept of the real because its description by Hick makes one consider it as inexistent? ${ }^{35}$

It is clear from Hick that this claim for the Real an sich is the deeper source and object of all religious soteriologies, thus ontologically unifies

${ }^{31}$ CF. P. Byrne, "A Religious Theory of Religion", 27. Hick answers this question saying that we know this from an inductive study or the phenomenology of human religious experiences.

32 CF. H. Netland, Dissonant Voices, 114-115 ;

33 CF. G. D'CosTA, John Hick's Theology of Religions. A Critical Evaluation, 173.

34 K. WARD, Op. cit., 311.

35 ibid., 311 "If $\mathrm{X}$ is indescribable by me, and $\mathrm{Y}$ is indescribable by me, it does not follow that $\mathrm{X}$ is identical with $\mathrm{Y}$. On the other contrary, there is no way in which $\mathrm{X}$ could be identified with $Y$, since there are no criteria of identity to apply. It is rather like saying "I do not know what $\mathrm{X}$ is, and I do not know what $\mathrm{Y}$ is, therefore $\mathrm{X}$ must be the same as $\mathrm{Y}$." 
them such that essentially the same process of moral and spiritual transformation is involved in all, which would mean that the process in each tradition has the same ultimate aim finally. Byrne sees in Hick something related with Feuerbach: that there is an element of human falsehood in the God worshipped by men, while agreeing that there is something real on which this projection gets to work, bringing one to conclude that Hick is aware of the difficulties and sometimes he presents arguments, which run against himself. ${ }^{36}$ Hick would contend that his view does avoid the conclusion that human religions are based on delusion.

\subsubsection{On The epistemological postulate}

Hick sees his Real an sic (divine noumenon) as the ground of religious experience and thought, making forms of religious experience across traditions veridical, inasmuch as they all constitute our conditioned and limited access to the Real an Sich. The real an sich impinges on culturally conditioned human consciousness, which for its part responds to and becomes aware of this impingement indirectly through the mediating senses of culturally diverse conceptui!! scheme. Thus, the noumenon is not directly experienced or known but rather only indirectly encountered in terms of concepts, structures and images generated at the entrance between the Real and different patterns of human consciousness. William Rowe thinks that this system of thought can make one draw all kind of conclusions and even hyper-criticisms because

"it suggests not only what Hick intends, that Real in itself, although beyond human concepts and direct experience, is, nevertheless experienced through the different divine phenomenal realities met with different religious faiths, but also, what he may not intend, that just as the phenomenal objects in Kant's philosophy are existing entities (cabbages, stones etc) so too the phenomenal objects through which the Real is manifested in various religious traditions (Yahweh, Allah, the Holy Trinity, Shiva, Brahman, Tao etc) are themselves actually existing beings or realities."37

Due to this possibility, George I. Mavrodes accused Hick of being polytheists. ${ }^{38}$ Mavrodes has an interesting critical reading of Hick especially on his magisterial book, An interpretation of Religion.

\footnotetext{
36 CF. P. BYRNE, Op. cit., 122-125.

37 W. Rowe, Op. cit., 141.

38 CF. G. I. Mavrodes, "Polytheism", 170-188.
} 
"In reading "An interpretation of religion" I got the impression that Hick thought that Allah, the Holy Trinity, Shiva were the gods worshipped in some various religions. And in some other religions the roughly corresponding objects of adoration were "impersonal ultimates" e.g. Brahman, and Tao. I also got the impression that all these were real beings. That is what led me to the conclusion that Hick was really a serious (descriptive) polytheists." 39

Rowe is convinced that Hick's own views are nearly affirming that gods are projections of the religious imagination, creations of the human mind through which we encounter what is truly the ultimate. ${ }^{40}$ For H. Netland the question is not only whether the eternal one can be experienced as personal and non-personal but more than that is whether its ontological status is such that it can be correctly be viewed as having both personal and non-personal without necessarily being so. For Netland, the several divine images seem to have clearly incompatible entailments. For example taking the implications of the Judeo-Christian image of the divine as Yahweh who according to its believers is ontologically independent, personal, creator, sustainer and righteous judge, with the implications for example of the image of the Nirguna Brahman or with the ontological ultimate concept of nothingness in Zen. The Kantian implications have influenced strongly on this distinction which is used in order make sense on the diversity of religious experience in general. 41

According to Hick, the epistemological consequences of the ontological postulate entails the relative insignificance of the differences in religious conceptualization and belief among traditions for these traditions are viewed as alternative soteriological frameworks in relation to the same ultimate reality and value. ${ }^{42}$

\subsubsection{His concept of religion}

Hick's revisionist concept of religion makes him to see the religions as essentially related rather than rival or stranger to one another. For him it is due to the superiority claims made by certain traditions that had developed such antagonism, which is more linked with the historical roots

${ }^{39}$ G. I. MAVRodes, "Response to Hick", 289-294.

${ }^{40}$ CF. W. Rowe, Op. cit., 142.

41 CF. N. Harold, "Professor Hick and Religious Pluralism", 259.

${ }^{42}$ CF. S. B. Twiss, "The Philosophy of Religious Pluralism. A Critical Appraisal of Hick and his Critics", 587. 
of Christianity in areas where existed the spirit of superiority even in their secular affairs as seen in the processes of colonization. All are concerned with the same vital process of moral and spiritual transformation that takes place morally and spiritually and transforms the subjects in different ways and in diverse cultural and historical settings. 43

The different religions are involved in working toward the same goal of human transformation mutually and complementarily rather than antagonistically. This view seems to bring Hick to the conception of a transcendental unity of all religions. Is there any problem to have a common transcendental union of all religions? Netland says that this transcendental unity contradicts the self-understanding of the religious traditions about their own beliefs. No religious tradition, faithful to her roots would be in agreement with the affirmation of a common transcendent, be it in the ontological sense, without even having to question epistemological references and conceptions, which can be as distinct as anything else. 44

This transcendental unity seems to be result of Hicks methodology, which, as has been said many times, aims at giving response to the diversity of religions in the world. So in order to keep on with this he has to deconstruct absolute claims.

"In proposing this deconstructive account and introducing note of scepticism about absolute claims Hick seems perilous close to committing the genetic fallacy, i.e. the fallacy of thinking that a causal account of the genesis of a statement or belief settles the question as to its truth of falsity. This sceptic view about religious belief is developed more extensively in his examination and assessment of differences in three principal types of beliefs advanced by religious traditions-historical, metaphysical and ultimate." 45

Hick proposes reasons for his scepticism and he doubted whether the differences between the different traditions could be settled in this life. Differences in historical belief among traditions while, in principle, settleable by historical evidence, usually are not settled because of the scarcity of data about many of the crucial founding events, which in some tradition are as important as anything else.

The differences involving metaphysical issues are presumably settleable in principle by referring to the actual states of affairs but the problem arises because they tend to involve the interaction of conceptual,

${ }^{43}$ CF. J. HICK, "The Non-absoluteness of Christianity", 16-36.

44 ibid., 541.

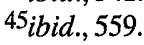


empirical and ontological issues so complex that it is extremely difficult to resolve conclusively matters of their verification and truth as for example in the case of the concept of God and the ultimate reality. This makes one to resort to the establishment of another method in which the phenomena of religious diversity can be given a response. The differences in the conception of the ultimate Reality are embodied within complex and hard to pin down, mythic and metaphorical rather than literal formulation, making it difficult to determine which tradition has a true conception of the ultimate reality. ${ }^{46}$

Despite his scepticism in settling the differences in belief in the life, Hick nonetheless powerfully defends the in-principled cognitivity of religious belief. It means that in the religious life there is a real belief about something, which is beyond the human capacity to interpret. He does this by appealing to the notion of eschatological verification, which involves the concept of an ultimate after-life situation capable of verifying the truth of religious claims about the nature of reality. ${ }^{47}$ The main critics of Hick say that in order to avoid saying that religion is an invention of man, Hick had tried to find a philosophical explanation, which instead of helping in making sense of different conflicting truth-claims, has ended up confirming what he is opposing. 48

Before entering into the theological objection, I would like to reflect as a bridge the logical inconsistence of the Hypothesis in as much as the question of truth and falsity is concerned. Mortimer J. Adler's, Harold Netland and Keith Ward have made logical reflection on the nature of truth that can help to illuminate the inconsistency of the hypothesis of Hick. ${ }^{49}$ According to M. J. Adler, the concept of truth as applied to religion can be interpreted in three ways: the poetical truth that applies to the narrative fictions, in dramas, and plays that is not generally subject to contradiction. The other is logical truth, which belongs to propositions, which can be descriptive or prescriptive and are subject to contradiction. Logical truth, if descriptive, is factual truth, that is; it gives knowledge of the observed reality. ${ }^{50}$ Hence, a true proposition according to him is that one which describes accurately an independent reality from the one who perceives it.

\footnotetext{
46 ibid., 559.

${ }^{47}$ CF. J. HiCK., "Religious Pluralism and Absolute Claims", 193-213.

48 CF. J. MORALES, "La teología de las religiones", 759-765.

${ }^{49}$ CF. M. J. AdLER, Truth and Religion, (New York, 1990).

$50 \mathrm{i}$ bid., 11-12.
} 
For those who hold that reality exists independently of the perceiver and that such reality is what it is no matter our own experience of it, then, truth would be defined as the agreement of our thought with the reality. ${ }^{51}$ We have to distinguish between the proposition in itself and our judgement about such proposition given because the truth or falsity of a proposition is absolute and immutable while our judgements on their correctness are relative and mutable. This is important in order to avoid some claims normally heard that this is true for this $y$ false for that. 52

The question on "what is truth" must be differentiated from the question: how can we ascertain the truthfulness or falsity of a given truth claim. For Adler this is important because the fact that one cannot empirically verify a given proposition does not necessarily influence its truthfulness of falsity. ${ }^{53}$ Following this, the problem that some articles of faith transcend the rational and empirical truth, this does not mean that such matters have nothing to do with the matters of truth. ${ }^{54}$

One of the basic notions of logic is the principle of non-contradiction. If a proposition $\mathrm{P}$ is true then the opposite of it not $\mathrm{P}$, cannot be true at the same time. The different truth claims must be either true of false. There is no an intermediate value because the law of excluded middle will reject it. 55 Now if two religions make two contradictory claims then such claims must be subjected to the law of non-contradiction because both cannot be true. Keith stress this saying that such principle plays an important role in such cases because revelation cannot contradict other knowledges and that it cannot simply be expressed in contradictions. ${ }^{56}$

For example, one of the basic beliefs of Islam is that there is only one God Allah and Muhammad is his prophet. If Muhammad is right, then Hinduism, which affirms that there are many gods, cannot be true or if it is true for Hinduism then Islam cannot be true. If Christianity says that Christ was the final and fullness of God's revelation while for Islam, Muhammad is the last prophet, one, of them should be false or true, or both are false, but not all of them can be taken to be true at the same time. If two religions contradict among themselves with regard the truth, one of them by definition must be false according to the law of non-contradic-

\footnotetext{
51 ibid., 21.

52 ibid., 12.

53 ibid., 21.

54 ibid., 19-21.

55 CF. I. M. CoPI, Introduction to Logic, 319-20. Also Cf. K. WARD, Religion and Revelation, 314-315.

56 CF. K. WARD, Op. cit., 322.
} 
tion. The fact that nobody has the ability to determine the correctness of such claims does not mean that the contradiction bound there, has no importance. K. Ward strongly attacks the tendency to eliminate rationality in religious matters. It is important to maintain rationality in the religion as elsewhere and that it should not be seen as a different kind of rationality from rationality in general.57

Netland shares the same view with Adler affirming that truth is a quality of propositions. It means that a proposition is true only when the state referred to corresponds to the description of such proposition, if not it would be false. ${ }^{58}$ For him the concept of truth cannot be neglected when one deals with religious phenomena. Even the claim that religions make truth claims is itself a truth-claim subjected under the principle of noncontradiction. 59

From those two thoughts, Hick would have hardships with regard to the different beliefs embodied in distinct traditions. Seeing that, Hick had to interpret them as myths but this goes against his previous affirmation as a realist and even a critical realist, (that the objects of perception exists independently of our perception.) This position of Hick does not separate him from those who affirm that religious language does nor refer to a reality that exists independently of the observer. ${ }^{60}$

The problem of Hick here is his effort to maintain two positions, which cannot be held together at the same time. Hick wants to maintain a realist position (that the religions make truthful affirmations) and his pluralistic hypothesis that all the religions are manifestation of the same reality an sich. He wants to maintain in one side that conceptions of the Real are authentic faces of the Real but in the other side, he does not accept that such faces be literally true but myths. From logical point of view, the position of Hick involves contradictions that make his hypothesis implausible up to the point of making some authors to deny him being a pluralist. 61

57 ibid., 320.

58 CF. H. Netland, Dissonant Voices, 114-115.

59 Ibid., 23-24.

60 CF. DON CUPIT, "The Death of Truth", 23-24.

$61 \mathrm{CF}$. K. WARD, Op. cit., 312. "In one sense he is not a pluralist at all- that is, a person who really believes that all the great religious traditions are equally authentic because he restricts the traditions he counts as authentic to those which accept the existence of a salvific transcendent reality." 


\section{PART II: THEOLOGICAL CRITICISMS}

When a society encounters another society that has different cultural systems, four possible responses can be resulted from such an encounter, says L. Newbigin. The first one can be that of rejection and putting up walls around the home ground; the second can be a surrender to the invader; the third can be a struggle to reform the existing plausible structures so that they can take and associate the new insights brought by the invaders; the fourth option could be wild pluralism: what is true for us may not be true for the others and so it is necessary to avoid or remove those features which are not good for them. The third option is the one, which will be adopted by a living culture for it will maintain and respect the values of each side. The fourth option if at all is opted; it would be a sign of approaching death of the invaded tradition. ${ }^{62}$ Christianity has encountered herself with this challenge and it seems that Hick has opted for this fourth reaction, which would make him accept all its consequences as has proposed L. Newbigin.63

\subsubsection{Christian identity: Christology}

Hick's option can lead -according Newbigin- to the death not only of Christianity but also of the other religions. Why? The problem, which Hick wants to solve, is that of a Christian who wants to dialogue with the believer of other world religions. This Christian needs a Christian base in which he will have to initiate his dialogue and even for such a dialogue to deserve the name Christian. It means that such a Christian must have all his claims in his way to the dialogue as a Christian and not as a neutral individual who has nothing to offer or to defend. For Eric O. Springfield, Hick's attempt to eliminate doctrines such as the incarnation may itself fall into dilemma because, either, the Christians have a subjective absoluteness for their belief in the incarnation or they should believe Hick and eliminate the incarnation as an objective doctrine and then lose their subjective certainty as Christians. ${ }^{64}$

They are Christians because God has taken flesh and has entered in the history of humanity. Without this faith, which is the basis of Christian-

\footnotetext{
${ }^{62}$ CF. L. Newbigin, "Religion for the Market Place", 135.

63 ibid., 135.

64 CF. E. O. Springsted, Op. cit., 25.
} 
ity, then as Newbigin has said above, it would mean that the death of Christianity is the imminent result. Now if Hick wants to call his approach or wants to solve a Christian problem should not try to destroy and surrender the same criteria, which qualify him to be a Christian. There is no any problem in making affirmations about the problem of religious diversity in the world. What cannot be accepted is to do it without the Christian guiding principles and especially if such affirmations deserve a Christian qualification and even worse if, it is to be called a Catholic one. The position of Hick seems to be like a case of medical that in facing a serious illness would opt to kill the sick person in order to end with the infirmity. I am sure that Hick would not go so far up to destroy Christianity but looking his arguments, it would not be easy stopping from making such a radical conclusion. Due to this, S. M. Ogden strongly rejects the pluralism as presented by Hick for it is a logical conclusion of the movement away from Christian absolutism as has been claimed, to another independent assertion with its own goal and other field of operation rather than Christian. ${ }^{65} \mathrm{He}$ might have forgotten that dialogue implies two irreducibly different subjects who share something fundamental even though with differences in some of their basic characteristics. ${ }^{66}$

One of the theological criticisms directed to Hick is in relation to his Copernican Revolution, which involves among the many conclusions, a shift from Christ centred to God centred and finally because of the traditions with impersonal conception, to Reality-centred, which is unknown directly. In order to facilitate the theocentric move Hick had to de-centre the belief on the incarnation. Hick has argued that Jesus should not be seen as God incarnate literally but metaphorically and mythically. ${ }^{67} \mathrm{~L}$. Newbigin sees this revolution proposed by Hick as exactly the opposite of the Copernican because it is a more subjective conception of the ultimate reality even than the Ptolemaic theology. He argues that a Christocentric view takes its stand on Jesus evaluating and judging the reality of life in a Christian perspective. For example, when a subject reads the New Testament, confronts with the person of Jesus whose words and deeds pose radical questions to the concerned with regard to his own ideals and prac-

${ }^{65}$ CF. S. M. Ogden, "Problems in the Case for a Pluralistic Theology of Religions", 505.

${ }^{66}$ CF. M. Dhavamony, "Jesus and the Gentiles", 208.

${ }^{67}$ Hick has already defined myth as a story, which is told but which is not literally true, or an idea, or image which is applied to something or someone but which does not literally apply but invites a particular attitude in its hearers. Thus, the truth of a myth is a kind of practical truth consisting in the appropriateness of the attitude, which it evokes. Cf. J. Hick, God and the Universe of Faiths, 166-87. 
tices. The church has taken this mystery of Christ as centre of her view of the world. The Hickian alternative leaves the subject with nothing for conceiving the Reality. Consequently, one has to form his own conception of the reality because all the particularities have been excluded in the conception of the Real. "Whatever concept is formed it is my own creation. It cannot call me into question. It is I who am at the centre." 68 Here one can see the deep influence of the philosophical thought of Kant. The revolution which Kant advocated and call it Copernican gave much emphasis to the subject or let us say to reason, such that the reason can interpret the reality whose structure depend on the reasoning subject, although he accepted that even reason itself has a limit. 69

W. Pannenberg says that for Hick Christology has become a stumbling block because he knows that by removing the place of Jesus he will have no problem in vindicating his pluralistic hypothesis. ${ }^{70}$

"The real theological Rubicon does not run between exclusivism and inclusivism, on the one side, and what he means by pluralism, on the other, it runs, rather, between two fundamentally different kinds of christologies: those which claim a constitutive significance for Jesus Christ and those which understand his significance to be representative only, however decisive."71

He continues with his insistence on the failure of Hick to see the importance and respect to each tradition with its claims:

"Whatever role doctrines such as incarnation play in a religion such as Christianity, it is not simply a statement of fact that arose from a misinterpretation of the founders' words. Rather they are the focal points of an entire way of life, intellectual, moral and spiritual-that includes and very much depends on regarding them as true and not myths in the pejorative sense."72

The problems which comes immediately in his argumentation is that changing beliefs about incarnation in Christian circles may as well result in changing a number of values associated with that belief, something that can be true for some doctrines in the other religions as well. This "mutual changing" of belief can be very difficult in some traditions. Thus speaking in a conservative form, the conditions, which Hick has set for entering in dialogue with non-Christians, would not be taken to be Christian

${ }^{68}$ L. NEWBIGIN, Op. cit., 142.

69 A. M. ANDALUZ, "Claves de la filosofía d e Kant", 10-17

${ }^{70}$ CF. W. PANNENBERG, "Religious Pluralism and Conflicting Truth Claims", 98-99.

71 Op. cit., 25.

${ }^{72}$ E. O. SPRINGSTED., Op. cit., 25. 
because there would be a failure in maintaining the certain facts and values, which have been traditionally associated with, and essential to Christianity. 73

J. Moltmann asks whether there can be Christianity without the cross or Islam without Sharia or Judaism without land thus concluding questioning wheter the truncated forms or religious pluralist identity would not be the beginning of the end of all dialogue. ${ }^{74}$ If dialogue is between Christianity with the other religions, then once those truth-claims, which seem to be forming the essence of such traditions, are thrown away then there would not be any dialogue by the way: a dialogue for what, if the reasons for the dialogue have already been removed! In these line J. B. Cobb, calls for a pluralism that would take into account the role of each religious tradition and its own understanding, purpose and the role of the religious element operating within such traditions. 75

For Hick, there was a first order religious experience of the presence of God in Jesus. Elsewhere he called it "the Christ event", which formed a starting point of the Christological interpretations of the church, but that must not be confused with any one of them (the different interpretations). ${ }^{76}$ However, at this point a critical note is necessary because the presence of God in Jesus was not firstly a product of religious experience but was Christ himself in his proclamations -which not only involve the present time but also involves the eschatological finality- that forms the basis of Christianity. The incarnational Christology is found on these claims of Jesus. So the claim of uniqueness is not based on the experience on the part of the early Christians. If not then it would be fair to argue for another unique experience in the other religions. W. Pannenberg stresses this saying that "the claim to uniqueness concerning the person of Jesus is bound up with eschatological finality of God's kingdom as becoming present in his activity."77

In his effort to demythologize the incarnation Hick seems to indicate that he does not pay much attention to the whole mystery of Christ, which is not only a product of some speculation but of a life, which was witnessed by a community which was born from its experience of faith. When he says that Christ should not be taken as totus dei (the whole of God) but

\footnotetext{
73 ibid.,

74 CF. J. MoltmanN, "Is Pluralistic Theology Useful for the Dialogue of World Religions?", 152.

75 CF. J. B. Совв, "Beyond Pluralism", 84.

76 CF. J. HiCK, God and the Universe of Faiths, 114.

77 W. PANNENBERG, "Religious Pluralism", 101.
} 
totus deus (wholly God), it reminds us that this concept has a stretch relation with the Calvinian controversy about the real presence of Christ in the Eucharist. Calvin taught that the Eucharist would transmit a communion with the body of Christ in heaven and not in the earth because he believed theat the finituma non capax infiniti. Why such recourse? It seems that such idea has been taken or inspired from the thought of Calvin who claimed that the finite is not capable of the infinite. Thus, the bread and wine, which are finite beings, cannot embrace the whole divinity that is infinite. Applying this to Jesus of Nazareth, it would be like saying that the divinity could not be incarnated totally in this finite being, Jesus of Nazareth. If this is accepted then the theme of incarnation as seen above by Hick should be the convenient one. Hick seems reduce the issue of incarnation as something occurring in other religions: that is to say, that the Logos would incarnate in the founders of the other religions because Logos, the Word being infinite would not empty himself totally in a unique finite being. What is questioned here is that even if it is an idea, which comes from the Christian history it was not applied in relation with the other religions. It was concerned with the salvation of the Christian depending on the promise of God, accepted by faith without human merit and especially in the controversy of the real presence of Christ in the species of bread and wine. Thus using this idea as way to substantiate the argument for the equality of the founders of the world religions, and as a way to grant equality to all religions cannot be accepted at all especially in the Roman Catholic tradition. Neither Calvin himself would accept that the logos were to be also incarnated in the other founders. 78

\subsubsection{On salvation}

Hick has related salvation to a Christian experience obtained in the present life, which involves transformation from self-centeredness to reality centeredness. With this view, there is no need of negating the same process as occurring in the other religions. The problem, according to $\mathrm{Pa}-$ nnenberg, is that this understanding is not the one advocated in the New Testament. Salvation was understood with reference to the eschatological judgement of God and participation in the communion of his Kingdom. (Cf. Mk 8:35, 10:26, Lk 13:13-30) ${ }^{79}$

\footnotetext{
${ }^{78}$ P. R. PANIZO, Op. cit., 44-45. The idea seem not only to have its origin in Calvin's Institutio IV,17 but also can be traced in Sententias III,22,3 of Peter Lombard.

${ }^{79}$ CF. W. Pannenberg, "Religious Pluralism", 101.
} 
It is possible that the great world religions are all concerned in some way with the theme of salvation but Hick seems to minimize the differences that are found in the different religions giving the impression that all the religions share the same and common goal in their soteriology and their understanding of what salvation is. Soteriology in the different traditions must have something more and distinct. For example, can we take Pauline theme of justification or the Hindu understanding of moksha ${ }^{80}$ or the Zen notion of satori 81 as the transition of the self-centeredness to reality centeredness?

Linked with the soteriological problem advocated by Hick is the Christian understanding of revelation, which is the result of relativising the truth claims within Christian faith. For C. Schwöbel a Christian theology of religions - like all other Christian theology although with different methodology - is grounded on the self-explications of faith in Christ as the rational reconstruction of the reality view built on the bases of Christian faith. "In its self-interpretation Christian faith as the existential relationship of absolute and unconditional trust in God-Father, Son and Sprit is seen as grounded in God's self-disclosure in Jesus Christ, which is authenticated for the believer by God the spirit." 82 Revelation is an aspect indispensable for any theology that claims to be a Christian one:

"Christian theology, which interprets itself as the self-explication of faith, therefore can be understood as a theology of revelation that sees everything human beings can assert confidently and faithfully about God and God's relation to reality as grounded in God's revelation as the condition of the possibility of faith. In the modern era the understanding of Revelation has in many strands of Christian theology been interpreted as self-disclosure; God does not disclose something about God, but God. The author and the content of revelation is identical. It follows from this that revelation is not understood as a specific aspect of divine action, which could somehow be separated from other aspects of God's activity." 83

The understanding of revelation is not a question of one's invention according to his own interest or as he likes to see it. The Christian faith is

${ }^{80}$ Moksha (enlightenment) for the Hinduism means liberation. It is the emancipation not from sin but from the Karma (action be it good or bad). This liberation leads to a condition in which there is neither time nor space, thus leading to a unity whereby all is considered one.

81 For Zen Buddhism Satori means enlightenment whereby the self and the world are transformed into one. The breath of the universe vibrates the subject, thus ceasing to be just a small subject and selfish ego. He becomes open and transparent in unity with all.

82 C. SCHWÖBEL, "Particularity, Universality and the Religions", 34.

83 ibid., 
build not on whatever kind of revelation but it is built on the historical revelation of God with a reality centred on the person of Jesus.

"The Christian church has from the beginning preserved the history and destiny of the particular first century Jew, Jesus of Nazareth as the foundational event in which God identified himself with the humanity. This particularity is not a transient and accidental aspect of the response to God's self-disclosure, but an essential element of the Christian understanding of how God interacts with creation in the spatio-temporal order. It is in the specific events of the history of Jesus that God identifies the divine being and will, and therefore this particular story serves as the paradigm for the assertions of the Christian faith." 84

G. D'Costa shares the same line of thought against theocentrism because for him, "whatever is said of the Father is said of the Son and so we cannot, as Christians speak of the Father without the story of Jesus. The Father cannot be conjured up through speculations or abstractions, but is revealed in particularities of Jesus history..." 85 D'Costa insists that the place of a Christocentric Trinitarianism is important for a valid Christian role in her relation with the other religions for it can help one to avoid the danger of isolating or separating the persons of the Trinity. ${ }^{86}$

From Christian faith perspectives, one cannot escape from the universality of God's presence in the particularity of religions, unless otherwise one has to change the doctrine on creation. The particular constitution of the convictions, however, excludes the theological possibility of talking about a plurality of revelations in religions.

"Revelation is an "achievement word" and in Christian theology it refers precisely to the personal certainty that is constituted where the truth of God's self-disclosure in Christ is authenticated in the Spirit as fundamental orientation for the life of a particular believer. Where one talks about revelations in other religions one has moved from the participant's perspective of Christian faith to the observer's perspective of the phenomenology of religion-which is of course, perfectly proper if one is not engaged in doing Christian theology but phenomenology of religion." 87

For Schwöbel to talk about true revelation in other religions is theologically reserved to Christianity not for superiority but by refusing to interpret them in such a way that they may fit a Christian understanding

\footnotetext{
84 ibid., 35-36.

85 G. D'CosTA, "Christ, the Trinity, and Religious Plurality", 18.

86 ibid., 27.

87 C. ScHWÖBEL, "Op. cit., 39.
} 
of revelation or to reduce them to match a particular general theory of religion which would imply doing injustice to these religions than justice. 88

Schwöbel is more radical against this tendency of acknowledging the presence of revelation in the other religions because to acknowledge revelation of another deity or illumination of another way of salvation means that this particular revelation now determines the personal certainty of one's-being-in-the-world and this would imply conversion. ${ }^{89}$

Thus, Christian theology of religions would lose its particular identity if it attempts to base its understanding of the religions not on the universality of God who is disclosed in Christ, but on some supposedly universal anthropological constant such as the postulated divine an sich of Hick. And, it becomes contradictory if it presents the understanding of the religions with the alternative of a theocentric or a Christocentric approach because its conviction of the universality of God's care for the whole of his creation is founded in the revelation of this universality in the Christ event, which becomes fundamental and basis for the Christian hope, love and faith. ${ }^{90}$

Pannenberg would put stress on the importance of the different and conflicting beliefs existing in the different religions since these divergences are part of the religious reality and are to be studied and be clarified be it from a Christian point of view or any of the other world religions. Furthermore, he says that,

"a theology of world religions that wants to be true to the empirical situation in the way the religious traditions confront each other must not evade or play down the conflict of truth claims as did Hick in his hypothesis. If we look to the history of religions in the past, there was always competitive and struggle for superiority on the basis of different truth claims. Although claims of this kind cannot be easily judged once for all, they nevertheless admit provisional judgement in terms of whether a religious tradition continues to illumine the life of its adherents in the context of their world." 91

The encounter of conflicting truth-claims challenges each religious tradition to reaffirm itself in facing those challenges. It would mean to incorporate whatever one has to recognize as elements of truth in the other traditions into one's faith. ${ }^{92}$ What cannot be accepted is to give up

\footnotetext{
88 ibid., 40.

89 ibid,.

90 ibid., 39.

91 W. PAnnenberg, "Religious Pluralism and Conflicting Truth Claims", 107.

92 J. MELloni, Los Ciegos y el Elefante, 16-119.
} 
on the specific truth-claims of one's own religious tradition for if it happens, it would be the end of that religious tradition. "Therefore, the advice of some promoters of a theology of religious pluralism to relativize and play down the Christian truth claims should prove disastrous." "93 That is why J. Dupuis observing this danger, is cautioning his readers: "We have thought it necessary to observe that Hick's recent thesis about such an undifferentiated ultimate goal as the "Real" is not in agreement with the Christian tradition." 94 The reason for this is that for the Christian tradition the Triune God is the ultimate goal of human life, the ultimate Reality that though remains beyond our human grasp, has nevertheless revealed himself in Jesus Christ. 95

If it is remembered, Hick defends his postulation of real an sich saying that even in the Christian circles, although God has revealed himself still he is believed to be ineffable to the human cognition. Hick draws support for his argument from classical orthodoxy Christiana theologians including Gregory of Nyssa, Augustine, Aquinas, and St. John of the Cross as well from Hindu and Islamic traditions. G. Loughlin sees some handicap in Hick's understanding of the ineffability within the Christian tradition, for while it is true that Christianity does not claim to know what God is in himself, it insists that it can only say what is not. It also believes and insists that God is definitely revealed in the life, death and resurrection of Jesus Christ. It is because God has first spoken, that Christianity can speak after him and speak of him as the one who is hidden, that God is unknown. For Christianity, God's self-saying, self-communication -to use Vatican II terminology- 96 is the ground of Christian faith. Against Hick, it must be insisted that, Christianity is aware that God is unknowable, understands that he cannot be understood; yet not because of a Kantian epistemology or some other philosophical speculation but because of God's word spoken in the concrete reality of history as life lived and death undergone, for it would be unbelievable to suppose that Christian theology is going to abandon her faith in the divine revelation in favour of an hypothesis, the noumenon postulated by Hick or to say that Christianity believes on that reality as has been explained by Hick. ${ }^{97}$

G. D'Costa accuses Hickian pluralism for intolerance because such pluralism eventually is intolerant towards most forms of orthodox reli-

\footnotetext{
93 W. PANNEnBerg, "Religious Pluralism and Conflicting Truth Claims", 103.

94 J. DuPUIs, Toward a Christian Theology of Religious Pluralism, 38.

95 ibid., 309. also CF. $D V, 2$.

96 CF. $D V, 2$.

${ }^{97}$ G. Loughlin, "Noumenon and Phenomena", 506-507.
} 
gious beliefs whether they are Christian or non-Christian. ${ }^{98}$ Sharing the same opinion, E. O. Springsted goes further criticizing Hick for some kind of confusion in his attempt to solve the problem of dialogue with non-Christians by criticising those who have tried to give a Christian and a more respectable theological solution to the problem of religious plura-lism. For example according to him, Hick should not criticize Karl Rahner's arguments, which lead to the conclusion that the non-Christians can be considered as anonymous Christians.

"I suggest therefore that the real problem of inter-religious dialogue is not, as Hick sees it, in removing those beliefs and values that appear to hinder dialogue because of their uniqueness but in engaging in dialogue given those beliefs and values. Rahner's arguments for admitting 'anonymous Christians' even if they are wrong at least seriously addresses this issue for they take into consideration the real faith commitment of the believers." 99

Seeing all difficulties one should agree with González Faus that looking from the scriptural source and especially the New Testament one cannot avoid suspecting that the religious problem of religions of the world is not well formulated. For him one has to distinguish what is the theological reflection of each tradition about the other religions, which in some sense can be merely an internal problem, which may have a little importance. This should be distinguished from the question about how the religions live together in the world. 100 According to him, it is Christianity, which encounters problems in relating to the world religions due to some affirmations, which in the end are not fulfilled.101 From this insight it seems that Hick does not make a clear distinction upon these and so putting the other religions in jeopardy for he does not take into account their claims, their position, their attitude towards Christianity and the other religions. It is necessary then to review the whole approach to the problem because as a Christian it is impossible to establish a proper attitude as propounded by Hick. The question would be again, how should Christians relate with other religious traditions and at the same time remaining faithful to their own traditions? There is a need for creative fidelity in reflecting this question.

\footnotetext{
98 CF. G. D'Costa, "The impossibility of a Pluralist View of Religions", 229.

99 E. O. Springsted, Op. cit., 26.

100 CF. J. I. G. FAus, "Dialogo interreligioso y diapraxis", 281.

101 ibid., 283
} 


\subsubsection{Inter-religious dialogue and creative fidelity}

The encyclical Ecclesiam Suam of Pope Paul VI issued in 1964 indicates the importance of dialogue as an element in the church renewal and the openness to the world, which formed also one of the key points of Vatican II. Thus, inter-religious dialogue is part of the general dialogue with the modern world. 102

The inter-religious dialogue and especially between the two great missionary religions of the world i.e. Christianity and Islam, ${ }^{103}$ has been and still is a serious problem nowadays and especially the search for criteria, which would enable such dialogue to flourish and persist even with the theological complications involved, without excluding cultural, economical, and the political problems. ${ }^{104}$ If it is not easy to judge the truthfulness of the religions, at least, there could be established some criteria, which could be objective, acceptable, respective to other religions and on Christian bases, which will help in making the world more harmonious with respect to the different beliefs. Cobb proposes that we judge the religions from two points of view -although with some complications- which include internal and external judgements. The internal one looks, studies and evaluates the claims of a given tradition, and sees if they are fulfilled. For example if a certain religious tradition claims to propagate a system of beliefs, which should lead -for example- to a just, peaceful and stable social order, it can be challenged to see if such claims have been fulfilled or are still being fulfilled. If it claims to provide opportunity for personal serenity and availability and compassion towards the others, then it can be asked whether these have been achieved when its precept are observed at

$102 \mathrm{CF} . G S, 92$.

103 CF. J. Bosch, Para Comprender Ecumenismo, 59. (From the data of the year 1990, the Christians form $32 \%$, (1,572 millions) while Muslims form $17.7 \%$ (851 millions)

104 CF. D. Tracy, Dialogue with the other, 27. In our times the issue of the relation between Christianity and Islam cannot be ignored due to the fact that one of them, Islam is now in a period of crisis with the modernity which is aggravated with its inseparability with the state thus leading to misunderstandings when it comes into contact with the Western democracy, especially in the way how religion is separated from the state. The situation is even more serious with the rising up of strong fundamentalism, which does not only reject any kind of dialogue but also are ready to die, they claim, for the sake of God, by talking about holy war, which in our modern eyes, is something absurd, unless otherwise there is a radical shift in the concept of God and holiness. Here one should not enter into the details and problems facing the world such as economic poverty and the effects of globalization, which in itself is good but when combines with wild capitalism, can lead to tremendous consequences especially to the weak economies thus breeding dissatisfaction whose consequence is the total rejection of whatever is occidental as something oppressive and injust. 
the most possible way. It is not easy to achieve such an evaluation but one can be in a position to apply such a judgement with a reasonable justification. Surely, in such process some will be better than others will, even when evaluated within their own tradition. What is difficult is to affirm generally that there is an equality of achievements and successes. Cobb sees the opportunity of the encounter of different traditions to be a good assumption with which to begin this process. 105

With respect to the external judgements, it is here where the problems arise because some do well according to some norms and others bad accordingly. Nevertheless, the important question is whether there is an objectivity of the norms applied, outside the community concerned. ${ }^{106}$ In fact, it is not enough to establish criteria of equality from the claims of each tradition just because they use, for example, the same terminologies or they claim to express the same reality, for one can find that the same expressions have different connotations. An example can help to illuminate this. Islam affirms that it worships God, the Christians affirms that they worship God. In a simple way, one can conclude that both worship the same "God", but when a deep analysis is done, there can be sufficient discordances between the two conceptions when one tries to look on the praxis.

The difficult that remains here is to find someone who can prove that their concept of God is equally the same for both. If we follow J. Cobb and put this in the internal and external judgements, we can check and see whether there is coherence between the objective notion of God or the preached God and the praxis of its worshipers. About this, W. Pannenberg puts an interesting question: "When a Hindu or Sikh prays to God, how can we know that in his intention it is the same God we worship? Even in the case of a pious Muslim, this is not clear, although in part we share the same 'cumulative tradition.' Is it nevertheless the same God? This is the question to be decided by God, not us." 107 Of course, no one can decide this but at least we can use the common sense to see some of the product of that tradition in the daily life in order to be able to discredit it as lacking a connection to such a supreme being, which should, at least in a Christian eye, be a source of love and mercy or peace and justice. If one coming out of his prayers goes directly to participate or realize actions against his/neighbour, no doubt that there is something lacking in the subject's prayer life without minding his belonging, whether a Christian or non-Christian.

105 CF. J. CoBB, "Beyond 'Pluralism", 85.

106 ibid.,

107 W. Pannenberg, "Religious Pluralism”, 103. 
The Christians' concept of God cannot easily be equalized with that of the other world religions as such since as a Christian, one does not participate in the faith of those religions in order to have the capacity of concluding that they have the same concept, nor the other religions have this capacity. In the questions of faith, one should not speculate something about the other's faith in which he does not share. The Christian affirmation of God is not an affirmation of words rather it has its line of practice, which influences even their life, and it has its principles that guide it. It is called Christian because there is something important connected with Christ, unless otherwise it would not be a Christian but something else.

\subsubsection{Religious freedom: A key to inter-religious dialogue}

The current times make one to rethink and try to read its signs in order to be able to have a good explanation for the plurality of beliefs and even how we relate ourselves with the followers of the other religions. We can use the categories of our time to establish human categories, (human because more than what is seen in the practices would be very difficult to be discerned and they can change at any time) which should be taken as measures for a "true religion" in the wide sense. Any religion, which goes against the general principles of humanity, should not be given the right to enjoy the benefits of religious freedom.

Religious freedom should be taken with an open eye rejecting all tendencies, which instead of promoting the human dignity do undermine or destroy it. There should not be any manipulation of such opportunity by some groups who might use it for their own advantage and thus propagating hatred, indifference and fear among the followers of the other religions. A religion, which undermine justice and peace or which defends injustices and violence and oppression does not deserve the name religion at least in our present world. Theologically or doctrinally, a religion may seem to fulfil some of the criteria but when it comes in the praxis things may be completely different. ${ }^{108}$

108 This could be seen for example in the case of South Africa during the Apartheid era, when some Christian churches such as the Dutch Reformed Church, supported such political system even using the Christian scriptures. In such a case, no matter what argument one can use such churches did not represent an authentic religion and even worse a Christian one following the teaching of Christ. This can be seen well discussed in "The Kairos Document," (Braamfontein, 1986), which is a theological comment on the political crisis in South Africa in times of strong apartheid regime. For the case, for example of Islam, there is no need to search 
Religious freedom would give as already said opportunity for the believers of different religions to have the freedom to know and approach different religions. Thus, such possibility in this pluralist world of religions can be made a reality if religious freedom is made a reality not only in the Christian environment but also in areas without Christian presence.

\section{Conclusion}

I will conclude this chapter with insights from Francisco Conesa who has made a thorough study of the concept of true religion, giving some useful insights on how the Christians should approach the other religions orthodoxically. ${ }^{109}$ For him the question of true religion should not be abandoned in the debate on religious pluralism. The problem of pluralism addressed by Hick is that it seems to affirm that all the religions are equally true. The International Theological Commission has rejected and rebuked this affirmation on equality saying that in saying that all religions are equally true is like saying that all religions are false. ${ }^{110}$

One should not confuse the truth of Christianity, which in an absolute sense corresponds only to Jesus Christ with its historical manifestations and realizations. As Christians, we believe that the relation between God and his people has been manifested and revealed in the person of Jesus Christ, but this does not imply that this has been perfectly achieved by the Christians. That is why there is a necessity of a continuous purification in the side of the Christians. The Christian relation with the other religions is a means of "walking together towards the truth."111 In this dialogue, the Christian can discover the good elements, which can be a demonstration of God's love to all humanity. In another way, the Christians have to be ready to understand and receive from the others the positive values without casting away their identity. This dialogical approach can help the Christian to discover and understand some aspects of their faith that might have gone unperceived.

for examples because in our times, there is a wave of elements, which can lead to the question of authenticity of Islam especially in its radical fundamentalism, which lacks control for there is no a centralized control of this religion. One may argue that Christianity did almost the same in her history, something true, but no doubt that, there are few if at all there are, who would say today that the Christians actions, which are against the general principles of life are from God.

109 CF. F. CONESA, Op. cit., 82-85.

110 CF. CIT, "El Cristianismo y las Religiones", [1996], n.13 cited in F. CONESA, Op. cit., 78.

111 Secretariado Para los no-Cristianos, "La Actitud de la Iglesia frente a los Seguidores de otras Religiones," n.13 cited in F. CONESA, Op. cit., 83. 
Dialogue is born from the essence of Christianity itself- in the incarnation. So reducing incarnation to a metaphorical and mythical nature in other words is to destroy the nature of dialogue. God in the dialogue, which has existed for centuries, has offered and continues to offer salvation to the humanity. To be faithful to the divine initiative, the church must enter in salvation dialogue with all. ${ }^{112}$ The base of any communication and in case of dialogue between the religions cannot depreciate the question of truth, nor should hide the truth. The question of truth and the search for the criteria of truth for all religions are part and parcel of any interreligious dialogue.

We can unite with the Second Vatican Council affirming that the members of the other religions are fellow travellers in the common road in which all the humankind are to pass, without forgetting that the church after many centuries of life runs towards the plenitude of divine truth. ${ }^{113}$ The Council did not affirm that the other religions are also ways of salvation because from Christian point of view that would be a self-contradiction from the very basic teaching on the divine revelation culminated in Christ. One may say that this is pure irrational exclusivism but from the Christian tradition, Christ came for all people and not for the Christians only. The Christians should be faithful to their tradition while accepting renovation and change of the humanly embedded obstacles, which impede opening herself to the other. This can be one of the interpretations of what the Council wanted to say on the Christians' attitude towards the other religions of the world without diminishing or destroying her identity. In this context of religious pluralism, the church (catholic) even with the Christians as a whole, are called to bear witness of what is proper to them, to defend their convictions with an attitude characterised by a spirit of dialogue and the will to serve in solidarity with all.114

\section{GENERAL CONCLUSION}

The hypothesis advocated by Hick is both provocative and innovative. It is provocative because it makes one think twice before drawing any conclusion whether critical or appraisal. It provokes the Christians to strengthen their faith because, by reading it, they can find it deficient as a

112 CF. Dialogo y Anuncio, n.38, cited in F. ConeSA, Op. cit. 84.

113 CF. DV, 8.

114 CF. I. Berten, "Pluralismo de las convicciones. Búsqueda de la verdad y sociedad. Algunas notas sobre la Declaración Dominus Iesus", 531-532. 
suitable Christian attitude towards the non-Christians. It is innovative in the sense that it instils a further search for a healthy means of relating in the religious diversity world, and making us aware of the situation and its difficulties. There is no doubt that the principles developed by Hick could be a source of confrontation with the different traditions that he intends to defend. This confrontation may increase exclusivism and inclusivism, which for him are not a healthy way of treating the other religions. The universalism, which is trying to defend, seems to be more tolerant and less violent than the Western exclusivism but it remains equally blind to the specific inner features of Christianity and the other religions as well. ${ }^{115}$ It is right that Christianity should not feel superior or develop a general attitude to absolutize herself. Neither should she relativize herself in order to please the others. Some of these Christian failures have linked her with the imperialist and the colonial domination on the non-Christians lands as Hick has accused her. ${ }^{116}$

The new map of faiths of the world as advocated by Hick can be used also as a tool to show that, even if the centre is not Christianity, or Christ it does not mean that all the different religions are in the same orbit. Using his Copernican map where the sun is the centre, the planets for example do not receive the same intensity of sunshine. There are some planets, which are near and others that are so far that there is no life in them, at least up to our present knowledge about them. The same way, the planets are not revolving around the sun in the same orbit. Each one has its own orbit. Using this example, although not the perfect one, the universe of faith whereby all religions would have had been revolving around the same divine an sich, unknown and experienced -as according to the place, culture where such process is taking place- can be objected showing that there must at least some values that can differentiate them. For example all cannot have the same intensity of the experience of the divine an sich (sun), and all cannot be treated as equals for some may have a remote light of the divine, something, which can make it a bit cold or hotter than the other as in the solar system.

One can object this saying that the earth -for example- although up to now is the only one known to have life, does not claim absoluteness as the only planet in the universe. Of course, it can claim that it is the only planet known to have life up to now. This is important for the creatures living in that earth and for them the earth is the only planet that can

115 CF. M. Dhavamony, "Jesus and Gentiles", 209.

116 CF. J. HICK, The Myth of Christian Uniqueness, 16-36. 
assure their life until something else is discovered. This does not mean that the other planets have nothing to do or they are good for nothing. May be they can be used as a help for further understanding of the earth and the nature of the universe.

The problem would be how to prove that such and such religion is near to the divine an sich than the other for Hick denied any direct relation with the divine an sich. Each religion can claim the same for no one knows which orbit is near and which is far. Here each religion will have the right to show if it is near to the divine an sich than the other not only in what it promises for the future life, but also for the general objective values, which can be accepted, not only within the same tradition but even outside traditions under normal circumstances. By normal circumstances, I mean that when there is peace, liberty, freedom and lack of cohesion in the matters of religion, in few words, religious freedom.

In the world with diversity of religions, each religion should keep and guard its faith and its tradition without confusing them with those of the others, while maintaining the readiness to accept and open to new innovations and changes. A Christian should be a Christian; a Muslim should be Muslim, and a Hindu a Hindu. What is required here is that neither one should despise the other nor insult each other. If there is such a possibility of living together and to be exposed to the different believers of the other traditions or the unbelievers would have the opportunity to evaluate the veridicality or the authenticity of the religions because the people under normal circumstances are not fools, if there is freedom of worship to accept whatever comes in their way unless there is a kind of brainwashing and radical fundamentalism imposed on them. It means that there could be a kind of competition but not whatever kind of competition, but a healthy one which will be born from the zeal to realize to its level best each of the requirements or better the conditions of a given tradition.

There should not be any prohibition, as it can be seen currently in some areas where it is not easy to operate if one is not a member of the state religion. In Christian lands, there should be openness towards the other religions like Islam, Hinduism or Buddhism and in the areas, without Christian tradition should not hinder the presence of Christianity in their lands especially in the Muslim dominated countries. This possibility will enable the people living in any of the religions to have something like an option in religious beliefs. For example, if in a certain tradition exists a certain conception of some values, different conceptions of the same values in other traditions, can help one to open his eyes and see that may be 
the belief held to be an objective one, finally is not always the case when it is compared and challenged with another, which is more objective.

As Christians, we cannot affirm our Christian uniqueness from the point of view of the other religions, because we do not share their attitudes and their affirmations towards us and perhaps for them it is not a problem. All the efforts to establish good relationship with the non-Christians should not only be a question of metaphysical proposition and epistemological claims, rather as something, which should be dealt with, especially in the life whereby one has to live peacefully with his neighbour who is not a co-religionist. It can be asked whether the situation of religious confrontations in the world today could have been eased by adopting the Hypothesis of Hick. If Hick has resorted to his hypothesis with the intention of taking away the imperialism propagated by Christianity, then he had resorted to another form of imperialism, which is to equalize all religions in order to leave them as they are. He might have forgotten -I thinkthat religions somehow are wrapped with some cultural matrices, which need purification and elevation. In addition, he did not take into account that religions do develop from time to time and so, this development can help in the purification of the religious categories and from some of deficiencies once taken to be the right ones. For example if 4000 years ago killing or human sacrifice in order to please God was seen as a value, today this has lost this interpretation and understanding because the concerned believers perhaps have understood better that such claims do not have to do with the divine. Abraham can be a good example of that.

Using the evaluation of the religions internally and externally, looking the coherence with values objectively accepted, one could establish some grounds for concluding that a certain religious tradition lacks fundamental principles, which would have given it credibility as a way of salvation or at least its merit as a religion. If not, the believers who are the heart of such traditions would be judges in evaluating, which religion is near or is walking towards the truth, but this presupposes, as I have said before, a genuine religious freedom and economic justice in order to avoid manipulation of the poor.

If one takes seriously, the proposal of Hick that all religions are equal would mean that there is no need of evangelization or missionary activity. This can be interpreted as a kind of egoism from Christian point of view and from social point view. I will argue. If what one believes is good for him and if he is a Christian, he cannot at all refrain from sharing with the others. If one says that this good is for my faith and not for the others, this 
can be regarded as unchristian. I think that a good understanding of evangelization is not due to superiority, which can always be a danger, but for the desire to share that good. An objection can be raised here that each tradition can claim doing the same. This is not a serious problem because the good intended should not subjectively conceived one. This can be evaluated from the basic teachings of the founders of the different religions or the important figures connected with such religions for example in the case of Christianity the teaching of Christ and the case of Islam, the Koran etc.

It cannot be more than true that Christianity, during its missionary activity mixed what was religious and political, but this does not eliminate the good intentions and good works realised by those missionaries who wanted to share the good with the other people. If we follow the positions of Hick, we can fall in the same trap but with different dimensions. Instead of sharing and purify our approaches, we would leave them alone because they have also the same religion. It is politics of its own kind. It is like saying that Christianity should not share some of the values, which might be missing in other religions and acquire those which are lacking in herself. Of course, Christianity does not need the other religions in order to be completely herself in terms of salvation for its faithful except in hereffort to understand better God's revelation. They can help her in understanding better the revelation of God because still Christianity is in the pilgrimage towards the fullness of God's revelation whereby God will reveal himself as $\mathrm{He}$ is.

Even though we cannot easily judge the different religions basing on their fruits as they can be found and seen, there are at least some external features, which can be used in the present time evaluation of the religions. Looking at Christianity, one can be tempted to say that, at least with regard to the external fruits she has tried to work hardly in understanding, correcting and developing values, which objectively could be accepted in areas where religious freedom prevails. It defends principles, which are humanly acknowledged and can be accepted in different cultural areas. It might have not managed totally in this but its readiness in accepting changes and correction can be taken as good sign. For example the Christian concept of God who is merciful, full of love to his people, a concept which has been purified stage by stage from that of the Old Testament up the to New Testament.

This concept, which is said to be accepted for example by the Christians and Muslims, can be taken as good indicator to evaluate these two 
traditions. If this concept is contradicted in the practice of the believers of any of the religions then there is a danger of concluding that something crucial is missing in the concerned religion. I say this for I believe that a religion is not only what is doctrinal but also the practises of that religion. If a certain religion would have scriptures which may be as good as diamond, but without followers, no doubt that such religion would be regarded as inexistent. If I am not wrong then, to say that the religions can be judged by their external manifestations and for a Christian, the teachings of Jesus Christ are the key for that judgement. Few people will affirm strongly that the religions can be judged for their eschatological or say their after-life fruits. The afterlife fruits are evaluated in the light of the present-day fruits as said St. Paul that the fruits of spirit are joy, peace, happiness etc.

For example the case of the women right and dignity among many others in a Muslim tradition can enlighten the point. Two women living in the same cultural environment but belonging to different religious traditions, one Christian and one Muslim, will have some difficulties on their position and role in that society. The Muslim woman has no right to many rights perhaps because of God's plan while the Christian woman may have more freedom and right and perhaps it is God's plan too. Nevertheless, how many "gods" are there if all religions are equal? The same God who is happy to see a woman been stoned and at the same time is claimed to be all merciful and all loving! Is there no need of saving this situation or there is no deficiency with such notion?

I am not really taking metaphysical examples or epistemological examples rather examples, which can be seen easily in order not to fall into the general conclusion, which can be drawn from the Hypothesis of Hick. As I said before that the two religions Christianity and Islam are claimed to conceive God as a loving God and merciful God, such concepts if taken seriously can help us to put into question some of the acts committed and still being committed by these two religions. The doctrines, which teaches or taught their believers that God is appeased for the death of a human being cannot be regarded as a true religion be it Christianity or any other religion. Christianity did bad things during the crusade and the inquisition but these were not the product of the teaching of Christ. This is important! Jesus was not in favour of violence strictly speaking if we read the Gospel seriously. In the present time then, religions, which propagate violence, for the sake of God, a religion, which encourage its believers to violence on false promise of meeting God directly by killing 
his fellow human being should be regarded as the negation of what a religion should be, unless otherwise there should be a radical change in the concept of God and religion as a whole. A religion, which keeps attacking the other religions instead of concentrating on its own, teaching, this is not a religion. It is barbarism.

I do not agree with Hick's hypothesis as the way to relate with the non-Christians. So Vatican II, - although accused by Hick of not being able to initiate a Copernican revolution- has initiated good measures, which can be a source of further development and study in the dialogue in the world with diversity of religions. Trying to establish a dialogue with the guidance of such a hypothesis would lead into a monologue because such a dialoguing Christian would go empty headed without his faith, which is the basis of the dialogue or such relation. The inter-religious dialogue is spiritual and religious, not a supra religious, social or agnostic or merely cultural factor. In order to have a true dialogue it is pre-supposed to be ready to listen to the other as other, and to listen means to be silent in oneself and to let the other speak to us, suspending our judgements, placing in brackets one's prejudices and vague evidences and traditional assumptions in order to be able to reveal and to discover what is the real essence of the different religious manifestations. This can help one to avoid making ridiculous affirmations about the plurality of religions, which involves downgrading the specific essence of each spirituality, which are the basis of such dialogue. 117

As already said, somewhere else that in such inter-religious dialogue the venture proposed by Hick, the relating subject would not be a Christian because already he had denounced his faith and his fundamental claims. Why should one occupy himself with the other religions if already he has thrown away the problems: the conflicting truth claims, salvation claims, revelation and even Jesus Christ? I believe that a good way of establishing and solving the problems concerned with the religious diversity, is not to commit self-termination but to start from her own tradition, searching the ways in which it can relate with them without neglecting them or judging them as contrary to their own conviction.

It is very difficult to find another way suitable than that of seeing them as our fellow brothers with whom we want to share our love and our good, which is nothing than sharing with them our faith that God the Father has revealed in His Son Jesus Christ who died on the cross and rose from the dead, and one day we will share with him the glory of his Father.

${ }^{117}$ CF. $A G, 11-12$. 
This is our God and not something, which has been postulated as a unifying factor for all religions, something unknowable, inaccessible even by the faith in the revelation of God. God has revealed what He is in himself and not something else.

A true attitude of dialogue is that which recognize the differences, the dignity of the subjects including all the fundamental aspects such as religious convictions and the system of thoughts held by the human beings concerned. This does not mean that the theme of truth is irrelevant and thus throwing away the contents of each tradition. In such dialogue there should be at least something more than a coexistence or symbiosis. Such dialogical encounter must give answer to exclusivistic attitudes, which can lead to violent confrontation and irrational proselytism, achieved in situations characterized with lack of freedom of the subjects be it economical, political or religious or all at the same time. This can be important in areas stricken by poverty as it happens in the parts of India whereby the Hindus accused the Christians for proselytism, manipulating the poverty situation of the persons concerned or in parts of Africa where there can be a danger of accepting religion for it is linked with Lords command to establish the Kingdom of peace and justice and thus fighting for rising up of the poor, which is something noble but not the only end of Christianity.

In this aspect, one can defend himself because sometimes with human cunning, one can claim that there have had been this kind of proselytism against the freedom of the subjects but it is not easy to show this especially in our present days on the Christians side. If it did happen in the past it can be understood clearly, that evangelization of the people is also related with time specific space. It is not easy to show that such or such individuals have embraced Christian faith due to the social economic benefit or by force in our present times. What is clear is that for Christianity to redeem the inhuman situations cannot be thrown away, even though it may happen that such activity is confused with proselytism. Where there is a genuine evangelization, the promotion of the people cannot be unappreciated. 118

This attitude of dialogue can be realized if the Christian knows well the teachings of his tradition and ready to face any possible change that may come in their encounters with other religions, as it is normal in any kind of human dialogue where there is a mutual sharing and serious discernment in both parts concerned.119 One can say without fear that in the

\footnotetext{
118 CF. EN, 31.

119 CF. P.R. PANIZo, Op. cit., 12-15.
} 
end the inter-religious dialogue in our times should not depreciate the value of shared life especially when it is realized without any negative interest. If we are Christians and Hick is as I think is, we should not undermine the power of the Holy Spirit, which works wherever he wills. Such possibility would enable us realize that even within the different conflicting claims in the distinct religions, the illumination of the Spirit penetrates there, bringing a mutual enrichment of such encounters. ${ }^{120}$

It is true that Christianity does not require the other religions as a compliment but the other religions can contribute something in the understanding of the revelation of God. Such is possible only if Christianity keeps her fundamental nature and understanding, without throwing them away in order to fit in the other religions framework. The adequate space for listening to the other religions would be created once we accept freely the genuine differences and become open to the suggestions brought by the diversity of religions, taking into account that religious diversity is not Satan's work rather can be the mysterious will of God.121

Thus the World Religions cannot continue with isolation nor live intelligently within situations of tension and enmity because man has become very dynamic in such a way that such religions should search for new ways in order to understand each other mutually and to relate and interrelate in an adequate manner. ${ }^{122}$ It is not a good way to establish an approach that would tend to disregard the imminent differences between the different religions.

The question that remains for us Christians and which will need further discussion is whether it can be accepted the unity of all religions in their diversities, assuming that it is within such possibility that the Christians can continue working intelligently with the help of the Holy Spirit accepting any consequence which may result from such work, knowing that even their witness can be an important conversion force for the nonChristians no matter whether they proclaim or they do not proclaim the Christian faith explicitly. ${ }^{123}$

120 CF. RM, 21; 28-29.

121 CF. J. M. SOSCKICE. "Introducción”, in: Concilium, 302(2003), 507.

122 S. PANneERSElVAM, "Una respuesta Hinduista a la Encíclica Papal, Fides et Ratio", 594.

123 The words of Vatican II that the Sprit of God fills the whole world permits us to rethink and see that God's work covers a broad field than that, which as human being are able to discern. CF. AG, 4; GS, 11; 15. 



\section{BIBLIOGRAPHY}

\section{Works of John Hick}

HICK, J., The Metaphor of God Incarnate, (London, 1977):167-185.

ID., "A Response to Cardinal Ratzinger on Religious Pluralism", in: Reviews in Religion and Theology, 1(1998):7-9.

ID., "On Conflicting Religious Truth-Claims", in: Rel. Stud. 19(4)1983:458-92.

ID., "Religious Pluralism and the Divine: a Response to Paul Eddy", in: Rel. Stud. 31(1)1995.

ID., "Response to Gerard Loughlin", in: Mod. theol. 7(1)1990.

ID., "Response to Robert Cook", in: Themelios, 19(3)1994.

ID., "The Epistemological Challenge of Religious Pluralism", in: Faith and Philosophy, 14(3)1997: 277-286.

ID., ed. Truth and Dialogue in World Religions, (Philadelphia, 1982).

ID., "The Philosophy of World Religions", in: Scott.j.theol. 37(2)1984:229-36.

ID., "The Possibility of Religious Pluralism: A Reply to Gavin D'Costa", in: Rel. Stud. 33(1)1997: 161-166.

ID., An interpretation of Religion. Human responses to the Transcendent, (New Haven, 1989).

ID., Death and Eternal Life, (London: Macmillan 1994)

ID., Disputed Questions in Theology and the Philosophy of Religions, (New Haven, 1993).

ID., "Eschatological Verification Reconsidered", in: Rel. Stud. 13(1977):189-92.

ID., Evil and the God of Love, (London, 1966).

ID., Faith and Knowledge, (Ithaca, 1966).

ID., God and the Universe of Faiths, (Oxford, 993).

ID., God has Many Names, (London, 1980).

ID., Problems of Religious Pluralism, (New York, 1985).

ID., The Myth of Christian Uniqueness. Towards a Pluralistic Theology of Religions, (New York, 1987): 16-36.

ID., The Myth of God Incarnate, (London, 1977).

ID., "Ineffability", in: Rel. Stud.36(2000):35-45.

ID., "Review of the Transcendent Unity of Religions by F. Schuon", in: The Ecumenical Review 28(3)1976:369-70

ID., "Christian Theology and Inter-religious Dialogue", in: World Faiths 103(1977):2-19. 
ID., "Whatever Path men Chooses is Mine", in: The Modern Church Man 18(1\&2)1975:8-17.

ID., "On Grading Religion", in: Rel. Stud. 17(4)1981:451-67.

ID., "On Conflicting Religious Truth-Claims", in: Rel. Stud. 19(4)1983:458-92.

ID., "Religious Pluralism and Absolute Claims", in: RounER, L., Religious Pluralism, (Indiana, 1984):193-213.

\section{Other authors}

AdLer, M. J., Truth and Religion: The Pluralist of Religions and the Unity of Truth, (New York, 1990).

Alemany, J. J., "El Dialogo interreligioso en el Magisterio de la Iglesia”, in: P. R. Panizo \& X. Quinzá (eds) Cristianismo y Religiones. (Bilbao, 2000): 245-270.

Almond, P., “John Hick' Copernican Theology”, in: Theology, 86(1983): 36-41.

Alston, W. P., “A Response to Hick”, in: Faith and Philosophy, 14(3)1997: 287-298.

Alvarez, G. M., (ed). La Pluralidad y el Sentido de las Religiones, (Salamanca, 2002).

Amaladoss, M., El Evangelio al Encuentro de las Culturas. Pluralidad y Comunión de las Iglesias. (Bilbao, 1998).

Andalus, A. M., "Claves de la filosofía de Kant", in: Imágenes de la $\mathrm{Fe}$, 383(2004):8-17

AQUINAS, T., ST II/II q.1 art. 2

Armour-Garb, B., "Betting on God: Why Considerations of Simplicity Won't Help”, in: Rel. Stud., 35(1999): 119-138.

Arregui, J., Urs von Balthasar: Dos Propuestas de Diálogo con las Religiones, (Vitoria, 1997).

Berten, I., "Pluralismo de las Convicciones. Busqueda de la Verdad y Sociedad. Algunas Notas Sobre la Declaración Dominus Iesus", in: Concilium, 302(2003): 527-536.

BARTH, K., Church Dogmatics. Vol. 1\&2, (Edinburgh, 1970): 280361,[Carlos Castro, La Revelación Como Abolición de la Religión, (Madrid, 1973)]

BASINGER, D., "Religious Diversity: Where Exclusivists Often Go Wrong", in: Int. j. Philos. Relig., 47(1)2000: 43-55. 
ID., "The challenge of Religious Diversity. A Middle Ground", in: Sophia, 38(1)1999: 41-53.

BeHRENS, G., "Feeling The Absolute Dependence or Absolute Feeling Of Dependence?", in: Rel. Stud., 34(1998): 471-481.

Bernhardt, R., La Pretensión de Absolutez del Cristianismo. Desde la Ilustración Hasta la Teología Pluralista de la Religión, (Bilbao, 2000).

BRunNer, E. The Christian Message in a Non-Christian World, (London, 1938).

ID., Revelation and Reason, (London, 1947).

Buckley, J. J., Seeking the Humanity of God. Practices, Doctrines and Catholic Theology, (Collegeville, 1992).

BYRNE, P., "A Religious Theory of Religion", in: Rel. Stud., 27(1)1991: $121-132$.

ID., "John Hick's philosophy of World Religions", in: Scott. j. theol., 35(1982): 289-301.

ID., Prolegomena to Religious Pluralism: Reference and Realism in Religion, (London, 1995).

CARRUTHERs, G. H., The Uniqueness of Jesus Christ in the Theocentric Model of the Christian Theology of World Religions: An Elaboration and Evaluation of the Position of John Hick, (New York, 1990).

CASCIARO, J. M., "Jesús en el Corán", in: Scr. theol., 30(1)1998: 13-37.

Clark, K. J., "Perils of Pluralism", in: Faith and Philosophy, 14(3)1997: 303-320.

ClOONEY, F. X., "The Inter-religious Dimension of Reasoning About God's Existence", in: Int. J. philos. Relig. 46(1999): 1-16.

CoBB, J. B., "Beyond Pluralism", in: G. D'CosTA, ed. CUR, (Maryknoll, 1990): 81-95.

Comby, J., La Historia de la Iglesia, 1: De los Orígenes al Siglo XV, (Estella, 1986).

COMISIÓN TEOLÓGiCA INTERnacional., "El Cristianismo y las Religiones (1996)", in: C. Pozo ed. Documentos 1969-1996, (Madrid, 1998).

CONESA, F., "Sobre la "religión verdadera." Aproximación al Significado de la Expresión", in: Scr. theol., 30(1)1998: 39-85.

Congar, Y., Vaste Monde, ma Paroisse, (Paris, 1959); Spanish transl. Amplio Mundo mi Parroquia, (Estella, 1965)

CoPI, I. M., Introduction to Logic, (New York, 1982)

CoRLISs, R., "Redemption and the Divine Realities: A study of John Hick and an Alternative", in: Rel. Stud., 22(1986): 235-48.

Cousins, E., "The Convergence of Cultures and Religions in Light of the Evolution of Consciousness", in: Zygon., 34(2)1999: 209-219. 
Cowdell, S., Is Jesus Unique? A Study of Recent Christology, (New York, 1996).

CuPIT, D., "The Death of Truth", in: New Statesman, (1991): 23-24.

D'CostA, G., "Christ, the Trinity, and Religious Plurality", in: G. D'Costa, CUR, (Maryknoll, 1990): 16-29.

ID., "The Impossibility of a Pluralist View of Religions", in: Rel. Stud., 32(2)1996: 224-229.

ID., John Hick's Theology of Religions. A Critical Examination, (London, 1987).

ID., "John Hick's Copernican Revolution: Ten Years After", in: New Blackfriars 65(769/770)1984).

ID., "Taking Other Religions Seriously: Some Ironies in the Current Debate on a Christian Theology of Religions", in: The Thomist, 54(3)1990): 519-529.

ID., "Theology and Religious Studies in a Pluralist Society: Towards a New Interdisciplinary Identity?" in: NTT 99(1)1998: 19-29.

ID., G., "Theology of Religions", in: ForD, D. F. ed. The Modern Theologians. An Introduction to Christian Theology in the Twentieth Century, (Oxford, 1994): 274-290.

ID., The Meeting of Religions and the Trinity, (Edinburgh, 2000).

DE LuBAC, H., Le Fondement Théologique des Missions, (Paris, 1961).

DEAN, T., ed. Religious Pluralism and Truth: Essays on Cross-Cultural Philosophy of Religion, (Albano, 1995).

Denzinger, E., El Magisterio de la Iglesia, D. Ruiz Bueno., ed. (Madrid, 1997).

DhaVAmony, M. "Religión", in: RenÉ LATOuRelle et al, (eds), DTF, (Madrid, 1992):1128-1151; 1218-1232.

ID., "Jesus and the Gentiles", in: Stud. mission. 51(2002):167-218.

ID., Teología de las Religiones, (Madrid, 1998).

DiNoA, J., "Pluralist Theology of Religions. Pluralistic or Non-Pluralistic?” in: D'CosTA, G., ed. CUR, (New York, 1990):119-134.

ID., "Varieties of Religious Aims: Beyond Exclusivism, Inclusivism, and Pluralism", in Marshall B. D., ed. Theology and Dialogue, (Notre Dame, 1990):249-274.

Divarkar, P., "Dos Grandes Modelos de Religiones en el Mundo", in: Sel. teol. 37(146)1998:145-151.

DuPuIs, J., "El Diálogo Interreligioso en Época de Pluralismo", in: Sel. teol. 39(153)1999:11-23. 
ID., "El Pluralismo Religioso en el Plan Divino de Salvación", in: Sel. teol.38(151)1999:241-253.

ID., "La Novedad de Jesucristo Frente a las Religiones Mundiales", in: Estud. Trinitarios. 32(1998): 3-37.

ID., Hacia una Teología Cristiana del Pluralismo Religioso, (Santander, 1991).

ID., Jesucristo al Encuentro de las Religiones, (Madrid, 1991).

ID., Toward a Christian Theology of Religious Pluralism, (Maryknoll, 1997).

DuRKheIm, E., Elementary Forms of the Religious Life, (London, 1963).

EDDY, P. R., "Religious Pluralism and the Divine: Another Look at John Hick's Neo-Kantian Proposal", in: Rel. Stud. 30(4)1994: 467-478.

FERRER, J., Filosofía de la Religión, (Madrid, 2001.)

FEUERBACH, L., The essence of Christianity, (New York, 1957).

Flannery, A., ed. Vatican Council II. The Conciliar and Post Conciliar Documents, (New York, 1981).

FoRGIE, J.W., "Hyper-Kantianism in Recent Discussions of Mystical Experience," in: Rel. Stud. 21(2)1985: 205-218.

FoRRESTER, D., "Professor Hick and the Universe of Faiths", in: Scott. j. theol. 29(1)1976

FrAZER, J., Magic and Religion. Abridged edition of the The Golden Bough, (London, 1944).

ID., The Golden Bough, (London, 1941).

GALl, R. S., "Different Religions, Diverse Gods", in: Int. j. philos. Relig. 49:2001: 33-47.

GefrRÉ, C., "Pluralismo Religioso e Indiferentismo. El Auténtico Desafío de la Teología Cristiana", in: Sel. teol. 40(158) 2001: 83-98.

Gellman, J., "In Defence of a Contented Religious Exclusivism", in: Rel. Stud. 36(2000): 401-417.

GILLIS, C., A Question of Final Belief: John Hick's Pluralistic Theory of Salvation, (London, 1989).

GoNZÁLEZ FAUS, J. I., "Diálogo Interreligioso y Diapraxis", in: ReLaTeol. 19(2000): 281-290.

GRIFFITH-D. G., “¿Es la Religión una Invención Occidental?” in: Concilium 302(2003): 511-521.

GRIFFITHS, P. J. \& LEWIS D., "On Grading Religions, Seeking Truth, and Being Nice to People", in: Rel. Stud., 19(1983):268-275.

GRIFFITHS, P. J., Problems of Religious Diversity, (Oxford, 2001). 
$I D .$, "Sobre 'Dominus Iesus.' La complementariedad es sostenible", in: Concilium, 302(2003): 27-30.

GunTon, C. E., "Indispensable Opponent. The Relations of Systematic Theology and the Philosophy of Religion", in Neue z. syst. Religionsphilos. 38(3)1996:298-306.

GuTHRIE, S. E., Faces in the Clouds: A New Theory of Religion, (Oxford, 1993).

HamnetT, I., (ed.), Religious Pluralism and Unbelief, (London, 1990).

Hebblethwaite, B., Ethics and Religion in a Pluralistic Age, (Edinburgh, 1997).

HeIM, S. M., "The Depth of the Riches: Trinity and Religious Ends", in: Mod. theol. 17(1)2001:21-55.

$I D .$, "The Pluralistic Hypothesis, Realism, and Post Eschatology", in: Rel. Stud. 28(2)1992:209-219.

ID., Truth and Difference in Religion, (Maryknoll, 1995.)

HewitT, H., (ed.), Problems in the Philosophy of Religion: Critical studies of the Work of John Hick, (New York, 1991).

InSOLE, C. J., "A Reply to Professor Hick", in: Faith and Philosophy 14(3)1997:299-302.

ID., "Why John Hick Cannot and Should not Stay out of the Jam Pot", in: Rel. Stud. 36(2000):25-33.

ID., «Non Est Hick», in: SENOR, T. D, ed. The Rationality of Belief and the Plurality of Faith. Essays in Honor of William P. Alston, (Ithaca, 1995): 216-241.

Inwagen, P. van., God, Knowledge, and Mystery: Essays in Philosophical Theology, (Ithaca, 1995).

JASPERS, K., Origen y meta de la historia, (Madrid, 1965)

JAYANTH, M., "De la Pluralidad al Pluralismo", in: Sel. teol 41(163)2002: 163-176.

Kant, I., Critica de la Razón Pura, Vol.1\&2, (Barcelona, 1985); ID, Critique of Pure Reason., trans: Norman Kemps Smith, (London,1958).

ID., Religion and Rational Theology. trans. Allen W. Wood \& George Di Giovanni, (Cambridge,1996).

KNITTER, P. F., "Toward a Liberation Theology of Religions", J. Hick \& Paul F. Knitter, eds. In: $M C U$, (New York, 1987):178-200.

ID., Jesus and the Other Names, (Maryknoll, 1996).

ID., One Earth Many Religions. Multifaith Dialogue and Global Responsibility, (Maryknoll, 1995).

Kraemer, H., La foi Chrétienne et les Religions non Chrétiennes, (Neuchtel, 1956). 
ID., (ed) The Unknown God, (New York, 1966).

ID., "The World Religions in God's Plan of Salvation", in: J. Neuner ed. Christian Revelation and World Religions,(London, 1967).

ID., Christianity and the World Religions. Paths of Dialogue with Islam, Hinduism and Buddhism, (New York, 1986).

ID., El Cristianismo: Esencia e Historia, (Madrid, 1997).

ID., Ser Cristiano, (Madrid, 1997).

LADARIA, LuIs F., "La Trinidad y la Misión Ad Gentes", in: Stud. Mission. 51(2002), 63-83

LINDBECH, G., The Nature of Doctrine, (Philadelphia, 1989).

ID., "The Gospel's Uniqueness: Election und Untranslatability", in: Mod. theol. 13(4)1997:423-450.

Loughlin, G., "Myth signs and significations", Theology 89(1986): 268-75.

ID., "Noumenon and Phenomena", Rel. Stud. 23(4)1987:493-508.

ID., "Prefacing Pluralism: John Hick and the Mastery of Religion", in: Mod. Theol. 7(1)1990.

MARKHAM, IAN., "Creating Options: Shattering the Exclusivist, Inclusivist, and Pluralist Paradigm”, in: New Blackfriars, LXXIV, 867 (1993): 33-41.

MAse, H. \& I. HisAKazu (eds), Explorations in Religious Pluralism: John Hick Studies, (Tokyo, 1995).

Mathewes, C. T. "Pluralism, Otherness, and the Augustinian Tradition", in: Mod. theol. 14(1):1998:83-112.

Mavrodes, G. I., "Polytheism", in: Senor, T. D., ed. The Rationality of Belief and the Plurality of Faith. Essays in Honor of William P. Alston, (Ithaca, 1995):170-188.

ID., "Response to Hick", in: Faith and Philosophy 14(1994):289-294.

MELLONI, J., "Los Ciegos y el Elefante. El dialogo interreligioso", in: Cuadernos Crisitianisme i Justicia, 97(2000):6-31.

Merrigan, T., "Religious Knowledge in the Pluralist Theology of Religions", Theol. Stud, 58(4)1997:686-707.

Michael, T., "Hacia una Pedagogía del Encuentro Religioso", in: Concilium 302(2003):625-634.

Min, A. K., "Dialectical Pluralism and Solidarity of Others: Towards a New Paradigm", in: J. Am. Acad. Relig. 65(3)1997: 587-604.

ID., "Christology and the Theology of Religions: John Hick and Karl Rahner", in: Louvain Studies 11(1)1986.

Miranda, MARIO DE FranÇA., "Jesucristo ¿un Obstáculo al Diálogo Interreligioso?” in: Sel. teol. 38(151)1999:219-230. 
Moltmann, J., "Is Pluralistic Theology Useful' for the Dialogue of World religions?" in: G. D'Costa, ed. in: CUR, (Maryknoll, 1990):149-156.

Morales, J., "Cristianismo y Religiones," in: Scr. theol. 30(2)1998:405-438.

ID., "La Reflexión Sobre las Religiones en el Siglo XX", in: Anuario de Historia la Iglesia 9(2000):277-294.

ID., "La Teología de las Religiones", in: Scr. theol.30(3)1998:753-777.

ID., "Revelación y Religiones", in: Scr. theol. 32(1)2000:47-74.

Netland, H., Dissonant Voices, Religious Pluralism and the Question of Truth, (Leicester, 1991).

Neville, R. C., "Religions, Philosophies, and Philosophy of Religion", in: Int. j. philos. relig. 38(1995):165-181.

NEWBigin, L., "Religion for the Marketplace", in: D'CostA, G., CUR, (Maryknoll, 1990):135-148.

NichOlson, R. A., The Mystic of Islam, (London, 1963).

NiElsen, N. C., Fundamentalism, Mythos and World Religions, (New York, 1993).

O'LeARY, H., \& SNYDER, D. H., "Are Beliefs about God Theoretical Beliefs? Reflection on Aquinas and Kant", in: Rel. Stud.32(1996):233-258.

Ogden, s. M., "Problems in the case for a Pluralistic Theology of Religions", in: J. relig. 68(4)1988:493-507.

Oтто, R., Lo Santo: La Racional y lo Irracional en la Idea de Dios, (Madrid, 1985).

PanIKKar, R. The Unknown Christ of Hinduism, Towards an Ecumenical Christophany, Rev.ed. (London, 1981).

PanneErselvam, S., "Una respuesta Hinduista a la Encíclica Papal, Fides et Ratio", in: Concilium 302(2003):593-605.

PANnenberg, W., Teologia Systematica, Vol. 1, (Madrid, 1992).

ID., "Religious Pluralism and Conflicting Truth Claims", in: D'CosTA, G. ed. CUR, (Maryknoll, 1990):96-116.

Placher, W. C., Unapologetic Theology. A Christian Voice in a Pluralistic Conversation, (Louisville, 1989.)

Plantinga, A., "Ad Hick", in: Faith and Philosophy 14(3)1997:295298.

ID., "Pluralism: A Defence of Religious Exclusivism", in: Senor T. D. ed. The Rationality of Belief and the Plurality of Faith. Essays in Honor of William P. AIston, (Ithaca, 1995):191-215.

QuINN, P. L., "Religious Diversity and Religious Toleration", in: Int. j.philos.relig. 50(2001): 57-80. 
ID., "Towards Thinner Theologies: Hick and AIston on Religious Diversity", in: Int. J. philos. Relig. 38(1995):145-164.

RACE, A., Christians and Religious Pluralism, (London, 1983).

RAHNER K., "El Cristianismo y las Religiones no Cristianas", in: $E T$ 5, (Madrid, 1964.):135-156

ID., "Los Cristianos Anónimos", in: ET 5, (Madrid, 1964):535-544.

$I D$. ., "El Cristianismo y las Religiones no Cristianas" in: $E T$, (Madrid 1964) a translation of "Christentum und nichtchristliche Religionen,", in: Schriften zur Theologie V. (Einsiedeln, 1961).

$I D$., "Historia del Mundo e Historia de la Salvación", in: ET 5, (Madrid, 1964.): 115-135

RATZINGER, J., "Der Christliche Glaube und die Welt-religionen", in: Gott in Welt II, (Freiburg, 1964):287-305.

$I D$., "Fe, Verdad y Cultura. Reflexiones a Propósito de la Encíclica Fides et Ratio", in: Rev. Esp. Teol. 60(2000):141-161.

ID., "Situación Actual de la Fe y la Teología", in: Communio 19(1)1997: 13-27.

RoBert, T., "From Theology to Religion," in: Mod. theol. 8 (1)1992:75-88.

Rodríguez Panizo, P., "El Pluralismo Religioso: Niveles, Modelos Aporías", in: R. PANIZO, P.\& X. Quinzá., (eds) Cristianismo y Religiones, (Bilbao, 2000):11-48.

Rose, K., Knowing the Real. John Hick on the Cognitivity of Religions and Religious Pluralism, (New York, 1996).

Rowe, W., "Religious Pluralism", in: Rel. Stud. 35(1999):139-150.

Runzo, J., "Perceiving God, World-Views, and Faith: Meeting the Problem of Religious Pluralism", in: SENOR, T. D., ed. The Rationality of Belief and the Plurality of Faith. Essays in Honour of William P. AIston. (Ithaca, 1995):242-260.

RusSell, S., "The Finality of Christ and Other Religions", in: Epworth Review 4(1)1977).

SAGI, A., "Religious Pluralism Assessed", in: Sophia 38(2)1999:93115.

SCARVAGLIERI, G., "Sociología de la religión", in: René Latourelle et al, (eds), DTF, (Madrid, 1992):1210-1218.

SCHELlenBerg., J. L. "Pluralism and Probability", in: Rel. Stud. 33(2)1997:143-159.

SCHINELLER, J.P. L., "Christ and Church: A Spectrum of Views", in: Theo. Stud. 37(1976): 545-566. 
SCHLEIERMACHER, F., On Religion: Addresses in Response to its Cultured Critics, (Richmond, 1969).

SCHLETE, H. R., Die Religionen als Thema der Theologie, (Freiburg, 1964).

SCHWÖBEL C., "Particularity, Universality, and the Religions", in: D'Costa, G., ed. CUR, (Maryknoll, 1990):30-46.

Secrectariado Para los No-Cristianos, " La actitud de la Iglesia Frente a los Seguidores de Otras Religiones", (1996).

SESBoüÉ, B., El Dios de la Salvación, Vol. 1. (Salamanca, 1995).

Sharma, A. (ed.), God, Truth and Reality: Essays in Honour of John Hick, (New York, 1993).

SILVER, D., "Religious Experience and the Facts of Religious Pluralism", in: Int. j. philos. relig. 49(1)2001:1-17.

SINKINSON, C., "Is Christianity Better than other Religions?" in: $E$. Times 107(9)1996:260-265.

ID., John Hick: Introduction and Assessment, (Leicester, 1995)

SLATER, P. L., "Hick and the Nature of Religious Truth", in: Studies in Religion, 24(1995):59-75.

SMith, W. C., Toward a World Theology, (New York, 1981).

Springsted, E., "Conditions of Dialogue: John Hick and Simone Weil”, in: J. Relig. 72(1)1992: 9-36.

StinnetT, T. R., "John Hick's Pluralistic Theory of Religion", in: $J$. Relig. 70(4)1990: 569-588.

Stone, J., “A Theory Religion Revised”, in: Rel. Stud. 37(2001):177189.

SuRIN, K., "A Certain "Politics of Speech": "Religious Pluralism" in the Age of McDonald's Hamburger”, in: D'CosTA, G., CUR, (New York, 1990):192-212.

ID., "Towards a "Materialist" Critique of 'Religious Pluralism': A Polemical Examination of the Discourse of John Hick and Wilfred Cantwell Smith," in: The Thomist 53(4)1989):655-673.

Tilley, T. W., "Christianity and the World Religions, a Recent Vatican Document", in: Theol. Stud. 60(1999):318-337.

Tillich, P., Christianity and the Encounter of the World Religions, (New York, 1963).

ID., Systematic Theology, 1-3, (Chicago, 1971).

ID., Teología de la Cultura y Otros Ensayos, (Buenos Aires, 1974).

Tomas, M. M., "A Christ Centred Humanist Approach to other Religions in the Indian Pluralistic Context", in: D'CosTA, G., ed. in: CUR, (New Cork, 1990):49-62. 
Torres Q, A., La Revelación de Dios en la Realización del Hombre, (Madrid, 1987).

TRACY, D., Dialogue with the other, (Louvain, 1990).

Troeltsch, E., The Absoluteness of Christianity and the History of Religions, (Richmond, 1971.) Spanish transl. El Caracter Absoluto del Cristianismo, (Salamanca, 1979).

Twiss, S. B., "The Philosophy of Religious Pluralism: A Critical Appraisal of Hick and his Critics", in: J. relig. 70(4)1990:533-569.

UríBARri B, G., La Emergencia de la Trinidad Inmanente: Hipólito y Tertuliano, (Madrid, 1999).

Vanhoozer, K. J., ed. The Trinity in a Pluralistic Age. Theological Essays on Culture and Religion, (Eerdmans, 1997).

VARILlon, F., El Cristiano ante las Grandes Religiones, (Bilbao, 1997)

Velasco, J. M., El Fenómeno Místico. Estudio Comparado, (Madrid, 20032).

ID., "Dios en el Universo Religioso", in: J. M. VELASCO/ F. SAVATER/J. G. CAFFARENA, Interrogante: Dios. XX Foro sobre el hecho religioso, (Madrid, 1996): 5-43.

Vilanova, E., Historia de la Teología cristiana I. De los orígenes al siglo $X V$, (Barcelona, 1987)

Vroom, H., "Do all Religions Worship the same God? in: Rel. Stud. 26(73)1990.

WAINWRIGHT, W., "Religious Language, Religious Experience, and Religious Pluralism", in: SENOR, T. D. ed. The Rationality of Belief and the Plurality of Faith. Essays in Honor of William P. Alston, (Ithaca, 1995):170188.

Walsh, K. A., "A Christian Theology of Religions and the Pluralist Paradigm", in: Science et Esprit 49(3)1997:281-314.

WARD, K., Religion and Revelation, (Oxford, 1993).

ZAEHNER, R., The Catholic Church and the World Religions, (London, 19649).

Kosmas. AsEnGA

Instituto Salvatoriano de Filosofía y Teología Moroporo (Tanzania) 